\title{
Early Portuguese meteorological measurements (18th century)
}

\author{
M. J. Alcoforado ${ }^{1}$, J. M. Vaquero ${ }^{2,3}$, R. M. Trigo ${ }^{3,4}$, and J. P. Taborda ${ }^{5}$ \\ ${ }^{1}$ Centro de Estudos Geográficos, IGOT, Universidade de Lisboa, Lisbon, Portugal \\ ${ }^{2}$ Departamento de Física, Universidad de Extremadura, Mérida, Spain \\ ${ }^{3}$ CGUL, Instituto Dom Luiz (IDL), Lisbon, Portugal \\ ${ }^{4}$ Departamento de Eng. Civil da Universidade Lusófona, Lisbon, Portugal \\ ${ }^{5}$ Escola Secundária Gabriel Pereira, Évora, Portugal
}

Correspondence to: M. J. Alcoforado (mjalcoforado@campus.ul.pt)

Received: 28 September 2011 - Published in Clim. Past Discuss.: 19 October 2011

Revised: 12 January 2012 - Accepted: 14 January 2012 - Published: 29 February 2012

\begin{abstract}
Natural proxies, documentary evidence and instrumental data are the only sources used to reconstruct past climates. In this paper, we present the 18th century meteorologists (either Portuguese or foreigners) who made the first observations at several sites in Continental Portugal, Madeira Island and Rio de Janeiro (Brazil), from 1749 until 1802. Information is given concerning observation site, variables observed, measurement period, methods of measurements and sources (both manuscript and printed). Some examples from the data usefulness are given: rainfall variability in Madeira (1749-1753) and in continental Portugal (1781-1793) was reconstructed, allowing to extend towards the late 18th century the well known negative correlation between the NAO index and seasonal rainfall. Furthermore, previously unpublished data for 1783-1784 have allowed analysing the consequences of the Lakagígar eruption in Portugal: foggy and haze days are referred to in summer 1783, but unlike the hot summer observed in northern and central Europe, temperatures in Portugal were lower than average. Additionally, observations from Rio de Janeiro in Brazil show that the Lakagígar consequences may well have spread to sectors of the Southern Hemisphere. Although the series are short, the data have been used for climate reconstruction studies and may also be useful to improve the quality of large scale reconstruction datasets.
\end{abstract}

\section{Introduction}

The last decades of the 20th century have testified a growing interest in historical climatology, e.g. the description of "climate and its variations during historical times and its impacts on society" (Brázdil et al., 2005, p. 365). This interest is not only due to academic curiosity, but mostly because the results of this interdisciplinary research field are also highly relevant for the current discussion on anthropogenic climate change. The knowledge of the natural climate variability has been deepened, and the availability of longer time series of relevant variables contributes to a more accurate understanding of the anthropogenic effects on climate.

Different authors have synthesised the types of sources used to reconstruct past climates from documentary evidence (diaries, memories, daily weather reports, ship logbooks, administrative and ecclesiastic archives, among others), from instrumental data and from natural proxies, such as treerings, corals, speleothems, boreholes, ice-cores (Brázdil et al., 2005, 2010b). The lack of sufficient documentary information has hampered studies dealing with the reconstruction of the climate of Portugal during the 17th and 18th centuries (e.g. Luterbacher et al., 2006; Camuffo et al., 2010 for a review). Therefore the relevance of all the 18 th century meteorological observations is clear. In this paper, instrumental data obtained by Portuguese and foreign observers for continental Portugal, Madeira and Rio de Janeiro (former capital of the Portuguese colony of Brazil) will be dealt with. 
The Enlightenment period was favourable to the development of scientific initiatives; the first observations begun in Europe in the late 17th and in the 18th centuries (Table 1), which is some time after the invention and development of the meteorological instruments. In the beginning of the 18th century, meteorology had much in common with both natural philosophy and applied mathematics; it overlapped these scientific branches and contributed to their development and to the progressive quantification of "natural philosophy" (Feldmann, 1990; Golinski, 2007). The meteorologists made essential contributions to the design of physical instruments, including the so-called meteorological instruments used to observe weather.

Several European scientific academies coordinated the first observers' work and encouraged systematic measurement of different weather elements. Unlike other European countries, meteorological observations at the end of the 18th century in Portugal were not performed at standard hours, neither with well-calibrated instruments (Taborda et al., 2004; Trigo et al., 2009). In fact, at this stage such observations were already standard procedure in other regions of Europe, such as Scandinavia (Bergström and Moberg, 2002), northern Italy (Camuffo, 2002a, b; Maugeri et al., 2002), France and United Kingdom (Jones et al., 1999; Slonosky et al., 2001; Slonosky, 2002; Golinski, 2007).

Most of the early instrumental records cover short periods, although a few meteorological sites are still active. A detailed description may be found e.g. in Kington (1988), Camuffo (2002a), Brázdil et al. (2005, 2010b), Lüdecke (2010) and Camuffo and Bertolin (2011). There was great progress in meteorological observations until the 1790s. Around 1790, several political events and war incidents, including the French revolution in 1789 and the following Napoleonic wars, disrupted a great number of networks. In any case, at the end of the 18th century these activities had made an impact on the Iberian scientists, thanks to the relative numerous contacts with foreign scientific academies, and the support of the state in the enlightened spirit of the time (Barriendos et al., 2000). The scientists' main areas of expertise were grouped in accordance with their foreign counterparts (medicine, physics, mathematics, and astronomy).

However, climate analysis was not a common procedure. "Climatology (...) existed in neither deed nor word in the early 18th century" (Feldman, 1990). The term would be used more widely only in the 19th century, with the purpose of compiling meteorological data, and performing temporal and spatial analysis.

Alexander von Humboldt (1845) refers that "The term "climate", taken in its most general sense, indicated [sic] all the changes in the atmosphere which sensibly affect our organs, as temperature, humidity, variations in the barometrical pressure, the calm state of the air or the action of opposite winds, the amount of electric tension, the purity of the atmosphere or its admixture [sic] with more or less noxious gaseous exhalations, and, finally, the degree of ordi- nary transparency and clearness of the sky, which is not only important with respect to the increased radiation from the Earth, the organic development of plants, and the ripening of fruits, but also with reference to its influence on the feelings and mental condition of men" (extracted from the English translation, Humboldt, 1858, p. 317-318).

The following decades were very important, not only to achieve quasi global coverage of measurements, but also to reach international agreement on the exchange of consistent weather information among different countries of the world, leading to the first and second international meteorological conferences of Brussels (1853) and Vienna (1873). It was also during this period that temperature readings became more reliable due to the widespread use of appropriate shading (e.g. Stevenson shelter), allowing better assessments on the evolution of climate at a particular location and comparisons between different regions.

In 1883, Julius von Hann gives a particularly "modern" definition of climate. First he states "By climate we mean the sum total of the meteorological phenomena that characterise the average condition of the atmosphere at any one place of the earth" and he goes on "That which we call weather is only one phase in the succession of phenomena, whose complete cycle recurring with greater or lesser uniformity every year, constitutes the climate of any locality. Climate is the sum total of the weather as experienced during a longer or shorter period of time at any given season" (Hann, 1903, definition extracted from the English version of the 2nd edition). Hann states the difference between weather and climate, highlights the use of average condition (average would be the statistical parameter more frequently used in the 20th century) and introduces the notion of weather type sequence, characteristic of each place and season.

Synoptical interpretation and simple forecast would be coined later, with increasing use throughout the 20th century.

The main objectives of the present work are: (1) to disclose the labour of the first meteorologists working in Portugal (both Portuguese and foreigners); (2) to synthesise the existent early Portuguese instrumental meteorological records of the 18th century, including data and metadata and to show their potentials for historical climatic studies; and (3) to demonstrate how the relatively short datasets obtained can be used to expand our knowledge on specific climatic events (e.g. the Lakagígar eruption in 1783/1784) or long-term variability (e.g. NAO and precipitation).

In the following section, an overview of meteorological observations in Europe during the 18th century is carried out and it is intended to introduce the meteorologists working in Portugal and overseas within the context of the scientific community of the late 1700 s. Next, in Sect. 3, the 18th century meteorologists are enumerated in chronological order and information is given concerning observation site, variables observed, measurement period, methodologies and sources. In order to illustrate the usefulness of the data dealt with in this paper, three topics are further analysed in 
Table 1. Early short instrumental series in Europe (Sources: Kington, 1988; Jones et al., 1999; Pfister and Barreis, 1994; Camuffo, 2002a, b; Brázdil et al., 2005; Lüdecke, 2010; Camuffo and Bertolin, 2012).

\begin{tabular}{|c|c|c|c|c|}
\hline Series/ network & Period & $\begin{array}{l}\text { Number of meteoro- } \\
\text { logical stations }\end{array}$ & $\begin{array}{l}\text { Science } \\
\text { Academy }\end{array}$ & $\begin{array}{l}\text { Organizer/ } \\
\text { Observer }\end{array}$ \\
\hline Rete Mediceae & $1654-1670$ & $\begin{array}{l}11 \text { stations } \\
7 \text { in Italy, } 1 \text { in France, } \\
2 \text { in Austria and } 1 \text { in } \\
\text { Poland }\end{array}$ & $\begin{array}{l}\text { Accademia del } \\
\text { Cimento }\end{array}$ & $\begin{array}{l}\text { Grand Duke of } \\
\text { Tuscany }\end{array}$ \\
\hline One series & $1665-1713$ & 1 station (Paris) & & L. Morin \\
\hline One series & $1706-1734$ & $\begin{array}{l}1 \text { station } \\
\text { (Delftt/Rijnsburg) }\end{array}$ & & N. Cruquius \\
\hline One series & $1716-1737$ & 1 station (Bologna) & $\begin{array}{l}\text { Accademia delle } \\
\text { Scienze e delle } \\
\text { Arti }\end{array}$ & J. B. Beccari \\
\hline Network in Central Europe & $\begin{array}{l}1717-1726 \\
1727-1730\end{array}$ & 11 stations & & $\begin{array}{l}\text { J. Kanold (doctor) } \\
\text { A. E. Büchner }\end{array}$ \\
\hline International network & $1724-1735$ & & $\begin{array}{l}\text { Royal Society of } \\
\text { London }\end{array}$ & J. Jurin \\
\hline National network (France) & $1778-1789$ & 22 stations & $\begin{array}{l}\text { Société Royale } \\
\text { de Médecine }\end{array}$ & L. Cotte \\
\hline National network (Italian Peninsula) & $1785-1811$ & 32 stations & & G. Toaldo \\
\hline International Network & $1780-1792$ & $\begin{array}{l}39 \text { stations from } \\
\text { Greenland to Rome } \\
\text { and from La Rochelle } \\
\text { to Moscow }\end{array}$ & $\begin{array}{l}\text { Societas } \\
\text { Meteorologica } \\
\text { Palatina }\end{array}$ & J. Hemmer \\
\hline \multirow[t]{2}{*}{ Spanish series } & $\begin{array}{l}1780-1825 \\
1737 \\
1786-1797 \\
1792-1799\end{array}$ & $\begin{array}{l}\text { Barcelona } \\
\text { Madrid } \\
\text { Madrid } \\
\text { Mahón (Baleares) }\end{array}$ & $\begin{array}{l}\text { Academia } \\
\text { Médico- } \\
\text { Matritense }\end{array}$ & $\begin{array}{l}\text { F. Salvá } \\
\text { F. Fernández } \\
\text { P. A. Salanova } \\
\text { J. Bals }\end{array}$ \\
\hline & $1786-1795$ & Cadiz & $\begin{array}{l}\text { Naval } \\
\text { Observatory }\end{array}$ & J. Sánchez Buitrago \\
\hline
\end{tabular}

Sect. 4: (1) precipitation variability in Mainland Portugal in the 1780s; (2) Lakagígar eruption impact in 1783; and (3) the link between precipitation and NAO index. Some conclusions are outlined in the final section. It should be emphasised that all datasets described here will become available at http://salva-sinobas.uvigo.es/index.php/eng/.

\section{Meteorological observations in Europe in the 18th century}

Most of the early instrumental records are not continuous in time (Brázdil et al., 2005). However, there are still some instrumental series and networks dating back to the mid 17th century, several of them related to scientific academies (Manley, 1974; Jones et al, 1999; Camuffo and Jones, 2002; Slonosky, 2002; Barriendos et al., 2002; Brázdil et al.,
2005, 2010b; Luterbacher et al., 2010; Camuffo et al., 2010; Lüdecke, 2010; Camuffo and Bertolin, 2011). The most important networks and short series of the 18th century are summarised in Table 1.

In the last decades of the 18th century, several meteorological treatises were published, the meteorological instruments were improved (see the classical texts by Middleton, 1966 and 1994), and new networks prospered under the initiative of scientific societies, such as the Société Royale de Médecine and the Societas Meteorologica Palatina. The latter was lead by the Mannheim Academy of Sciences from 1780 until 1792 and it influenced significantly most early Portuguese meteorologists. This renewed interest in meteorology was related to two facts: on the one hand, the application of meteorology to health and to agriculture and, on the other hand, the development of experimental physics. 
The Societas Meteorologica Palatina "was the first purely meteorological society to be established (in Mannheim) with the primary object of predicting the weather by analysing data collected from a network of stations making systematic daily observations" (Kington, 1988, p. 12). Moreover, it fostered an international network aiming at gathering comparable meteorological observations and, additionally, sent meteorological instruments to every institution and/or observer willing to participate. In this way, the network was capable of extending itself to several European countries. In a speech at the Mannheim Academy in 1780, Johann Hemmer, court chaplain and director of the Palatina Society, "proclaimed agriculture and medicine to be the primary motives for the project" (Cassidy, 1985).

To a large extent, the meteorological activities of many physicians were prompted on the neo-Hippocratic hypothesis concerning the influence of climate on human health (Demarée, 1996; Brázdil et al., 2005). In fact, the Greek physician and philosopher Hippocrates (460-377 BC), usually regarded as the founder of western medicine, considered the disease as the result of an inbalance between the organism and the environment, including weather and climate (Brázdil et al., 2005).

Meteorological observations were carried out with the aim of understanding the effect of weather on human health and "this hypothesis led to an interest beyond measure in human and animal epidemics" (Demarée, 2004, p. 30), including the first continuous meteorological observations in Lisbon by Marino Miguel Franzini, in 1815 (Alcoforado et al., 1997). However, the advent of bacteriological theories of disease in the late 19th century threw the discredit on those theories.

"Agriculturalists hoped that regular observations would succeed in correlating the weather with the success of crops" (Feldmann, 1990). The activities of the Royal Society of Agriculture of Paris, created in 1761, illustrate this fact. Its publication, which was issued four times a year from 1785 until 1791, included meteorological information, as the correspondent members were deeply interested in understanding the relationships between weather and agriculture (Pueyo, 1995). From the 277 memoirs issued by the Society, 24 are totally devoted to meteorology and 18 include either comments on meteorology or data. Cotte, who would be responsible for a 22 stations network from 1778 to 1789 (Table 1), was among the active members of the Royal Society of Agriculture (Pueyo, 1995).

This link between climatic conditions and agriculture production can be even more relevant in regions with lower crop yields and high inter-annual variability, such as most of the Mediterranean basin, including Portugal, when compared to Northern France and England. In fact, the major meteorological features controlling the development of crops in Portugal, such as cereals (Gouveia and Trigo, 2011) and wine (Gouveia et al., 2011), are highly dependent on the annual cycles of precipitation, soil moisture, humidity, solar radiation and temperature. Thus, all these aspects produce some impact on the harvest quantity and quality, and can cause episodes of food shortage and famine, sometimes even epidemics (Xoplaki et al., 2001; Trigo et al., 2009).

\section{Meteorological observations in Portugal and Overseas}

The last decades of the 18th century are marked by the institutional integration of Portugal in the Enlightenment, after a long period of scientific stagnation that was partially amplified by the catastrophic destruction of Lisbon during the 1755 earthquake (that implied the allocation of significant resources for the reconstruction effort in the following decades (Baptista et al., 2003). In spite of this, two events had most probably an important influence on science development in Portugal: the education reform lead by the powerful Prime Minister at the time, the Marquis de Pombal, in particular at the University of Coimbra (1772); and the foundation of Lisbon Royal Academy of Sciences (LRAS) in 1779 (Nunes, 1997).

The LRAS encouraged the development of scientific research, including Meteorology, that together with Chemistry, Anatomy, Botany and Natural History, were included in the first of the three classes in which the LRAS was structured. Moreover, the LRAS was offered newly built thermometers, barometers, hygrometers and "areometers" (apparently precursors of anemometers) in 1780, by the Societas Meteorologica Palatina (Peixoto, 1997). This gift would have also contributed to the development of meteorology in Portugal. The publication of the first meteorological observations and of meteorological studies in the Memoirs of Physics and Mathematics of the LRAS also denotes its interest in this new science.

In the following subsections, the meteorologists will be listed following the chronological order of their observations. Information will be given on station location, period of observation, variables registered and units and instruments used (whenever available). All the data have been digitised and converted to SI units (Lamb, 1986). Some evident typographical mistakes have been detected and corrected. The digitalized and checked data will be accessible at http://salva-sinobas.uvigo.es/index.php/eng/. We must acknowledge that there are large disparities in the amount of data and metadata available for each observer described below. Nevertheless, we are firmly convinced that the combined information provided is a valuable and useful tool to extend long-term climatic series for the regions represented. 


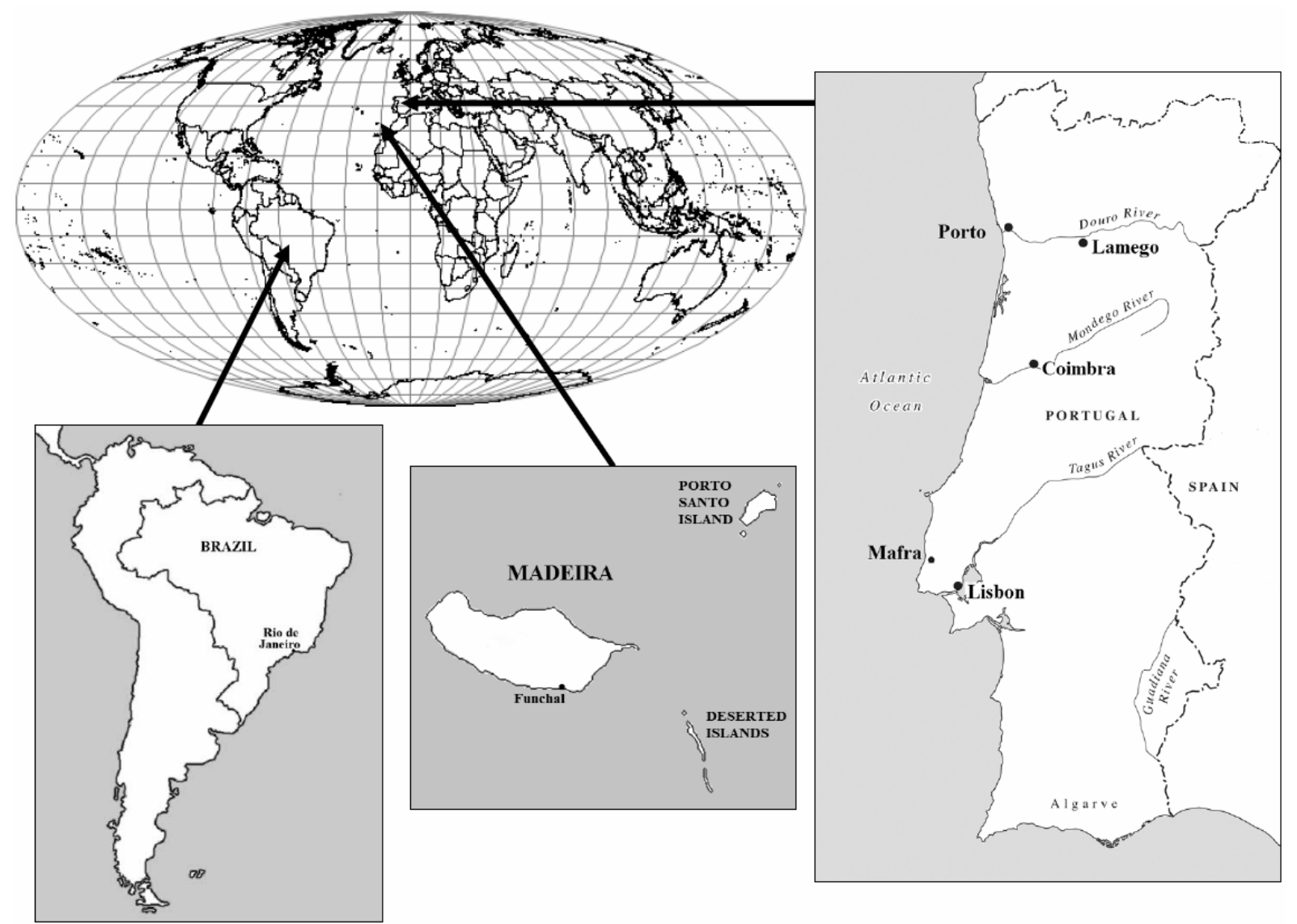

Fig. 1. Location maps.

\subsection{Thomas Heberden (Funchal, Madeira, 1747-1753)}

Thomas Heberden was a physician, fellow of the Royal Society (elected in 1761). He practised medicine on the Spanish island of Tenerife and also in the city of Funchal (capital of Madeira archipelago, Portugal, Fig. 1) and was one of the earliest physicians recommending Funchal as a sanatorium resort for chest disease patients. His brother, William Heberden, was an eminent London physician. Thomas Heberden shared his brother's interests in various aspects of natural philosophy, communicating through a number of papers sent to the Royal Society between 1756 and 1769 (Heberden, 1761, 1765, 1769 and 1770). Moreover, he published two papers on Madeira climate, including meteorological records (Heberden, 1751, 1753).

Heberden $(1751,1753)$ supplied monthly and annual data from Funchal from 1749 until 1753: temperature (Fahrenheit scale), air pressure and precipitation, measured twice daily at 07:00 and 15:00 LT (Fig. 2). We can assume that he refers to local time. No information is given referring to the exact observation site in Funchal, and within this city there is a large gradient of temperature and precipitation due to distance to the sea, steep slope and urban geometry (Lopes et al., 2011).
He used two thermometers: one exposed on the north side of his house to the open air and the other placed indoors, allowing him to make a comparison between two thermometers. Rainfall is measured using a "funnel 15 inches [i.e. $38 \mathrm{~cm}$ ] in diameter".

Heberden (1751) lists the monthly data from the barometer and thermometer for the years 1749-1750 and the monthly means of precipitation for the years 1747-1750. Heberden (1753) updates the monthly barometric and thermometric data for the period January 1751-June 1753. He presents a table with the monthly totals of rainfall for the years 17511753 and provides some statistical values. Finally, he lists the number of rainy days and the highest total of daily rainfall for each month. Figure $3 a$ and $b$ shows monthly temperature and pressure recorded in Funchal, where we can notice the hot summer of 1752 and the drop in pressure in early 1750 . Figure $3 \mathrm{c}$ shows the monthly rainfall and number of rainy days, while Fig. 3d provides the largest daily amount of rain per month.

Heberden (1753) adds several comments referring to significant meteorological situations and their consequences for humans and agriculture. For example, "the years 1749 and 1750 were such dry years, that the corn was destroyed, and 


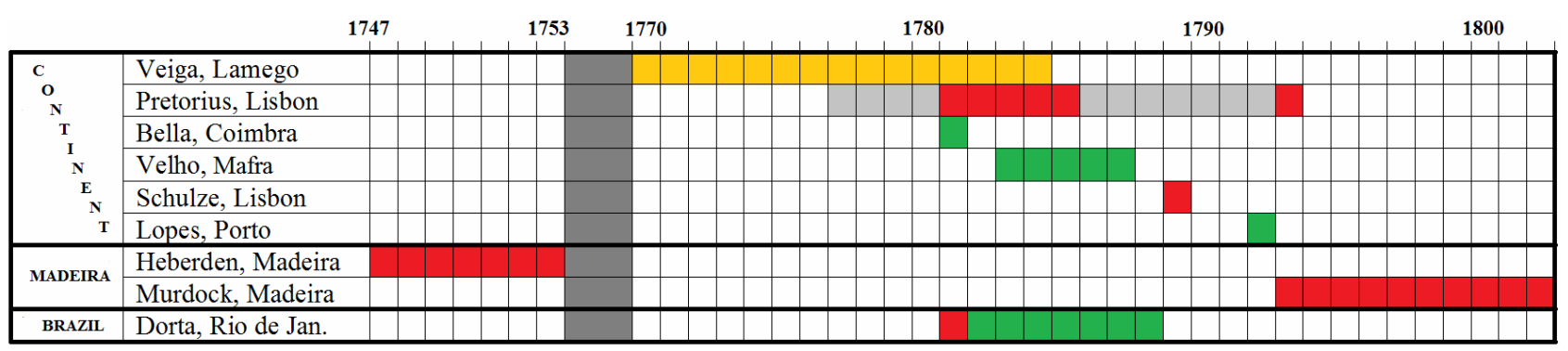

Fig. 2. Meteorological data availability in Portugal and overseas during the 18th century (yellow: annual data; red: monthly data; green: daily data; grey: lost data).
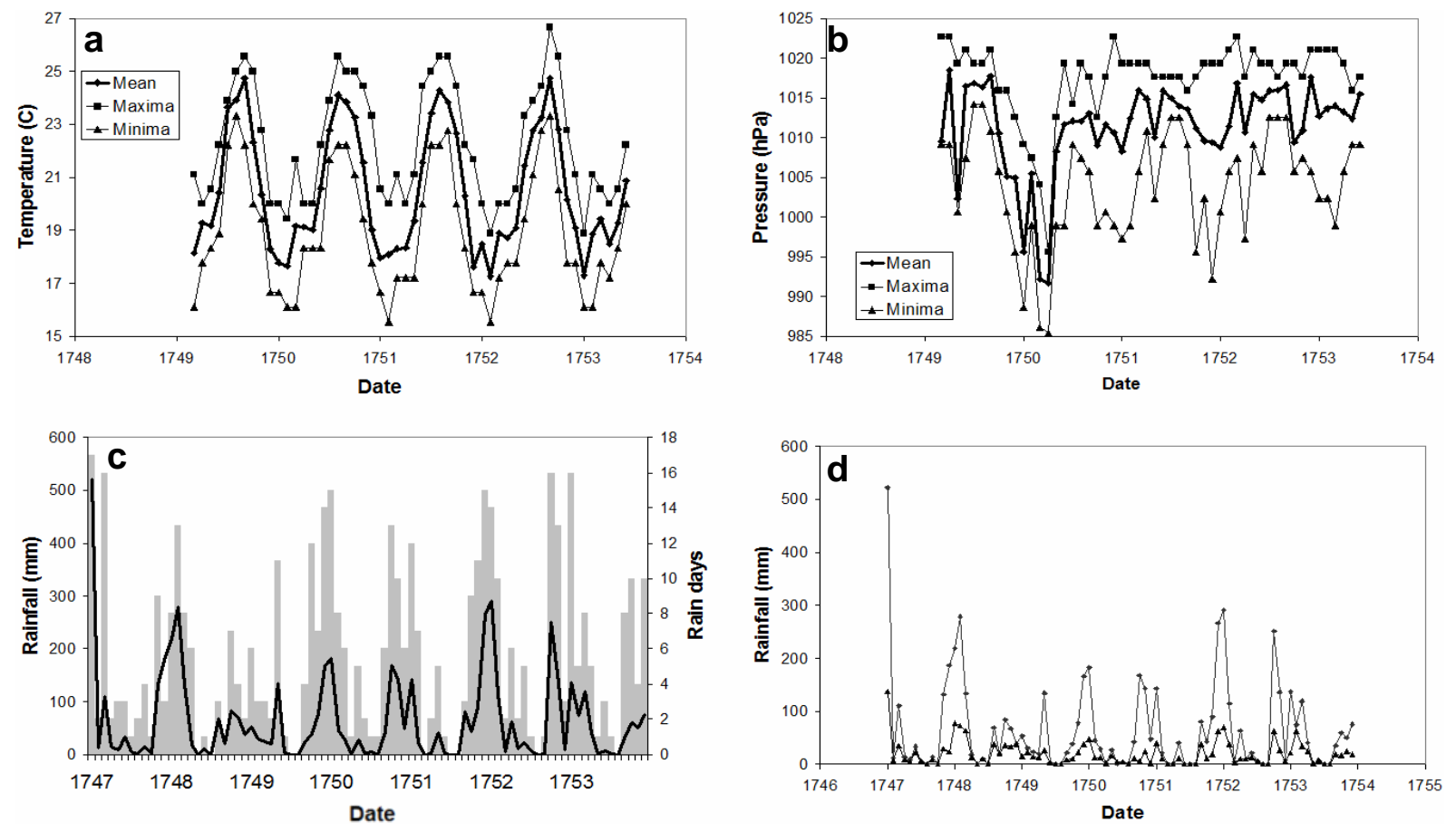

Fig. 3. Meteorological parameters recorded in Funchal by Heberden from March 1749 to June 1753 (temperature and pressure) and from January 1747 to December 1753 (rainfall). (a) Monthly temperature values. (b) Monthly pressure values. (c) Monthly rainfall (dark line) and number of rainy days (grey bars). (d) Monthly rainfall (grey line) and largest daily amount of rain per month (dark line).

the fruit-trees suffered much, particularly the peach-trees, the fruit either falling to the ground, whilst green, or, if it remained longer on the tree, being full of white worms" (Heberden, 1753). He also refers to the hot winds from the East (called Lesté or Levant) in October 1749, February and March 1750, "that are very troublesome" and he established its consequences on human comfort, concluding that "the remedy is to keep ourselves withindoors" (Heberden, 1753).

Heberden's data were compared with more recent ones (1980-1994). Eighteenth century temperature values are found to be 1 to $2{ }^{\circ} \mathrm{C}$ above present time corresponding timeseries. In fact, we can stress the similarity between historical minima and modern mean temperatures. However, too many geographical and instrumental parameters may have biased temperature values and direct comparisons may not be carried out directly.

\subsection{Veiga (Lamego, 1770-1784)}

To the best of our knowledge, the earliest records undertaken in continental Portugal were carried out by João de Sousa Freire de Araújo Borges da Veiga (Veiga, hereafter) in Lamego, from 1770 until 1784 (Fig. 2). Lamego was an important and prosperous Episcopal city of the Douro valley (Fig. 1), and was marked by economic productions: silk (the 16th-17th centuries) and Port wine (since the 18th century). 
There is scarce information concerning Veiga's life, although there are some facts worth to be highlighted (Taborda et al., 2004). Although he was a correspondent member of the LRAS (elected in 1785), he began his meteorological observations in 1770 , well before the LRAS foundation. His knowledge and interest on meteorological observations came most probably from his contacts with foreign colleagues. Nunes (1997) refers two foreign scientists with whom Veiga was in contact: João Serrano, Experimental Physics Professor at the Colegio Imperial in Madrid and the French Abbé Richard, who wrote a 10 volume work on "Natural History of air and meteors". Furthermore, astronomy was also within Veiga's interests: he published a small booklet on astronomical observations in Salamanca (Nunes, 1997).

The Lamego series consist of tables of annual values (extreme, average, totals) of temperature, precipitation and wind direction. To these, Veiga added the number of sunny, cloudy and partially cloudy days, but unfortunately only referring these as an average of the 15 studied years. Veiga adds a number of qualitative comments on the weather (mostly extreme events, such as the hot 1766 summer), not only relative to the studied period, but also to the preceding years. $\mathrm{He}$ also states that the strongest rainstorms are due to west and south winds and that they occur mostly from October until April, which is in agreement with modern objective assessments (Trigo and DaCamara, 2000; Fragoso and TildesGomes, 2008). Quantitative and qualitative information is included in the manuscript "Meteorological observations made in Lamego", that he offered to the LRAS (Veiga, 1784).

Veiga's observations site and measurement methods are unknown. At the end of the manuscript, there are some comments made by a member of the LRAS in charge of quality control of meteorological data (probably Pretorius - see Sect. 3.3, Nunes, 1997). Measurement methodologies were criticized, particularly referring to temperature and air pressure. In this regard Veiga was asked to send detail daily tables for a whole year in order to allow the verification of his data. However, no reply from Veiga has been found so far and consequently temperature and pressure data from Lamego will not be dealt with. Precipitation data were used to evaluate inter-annual variability for the $15 \mathrm{yr}$ of available data (Fig. 4), although their comparison in absolute terms with current climate normals are strongly limited, not only because the Lamego station does not exist nowadays, but mainly because some doubts persist referring to Veiga's observation methodologies and instruments. The average of the period 1770 $1784(526 \mathrm{~mm})$ is clearly inferior to the value we may infer from Daveau (1977) detailed precipitation map of Portugal (between 900 and $1000 \mathrm{~mm}$ ). Furthermore, the rainfall average (1960/1961-1989/1990) available for a nearby station (Tarouca, located at a similar altitude) reaches $1000 \mathrm{~mm}$; the latter is in accordance with Daveau's (1977) map.

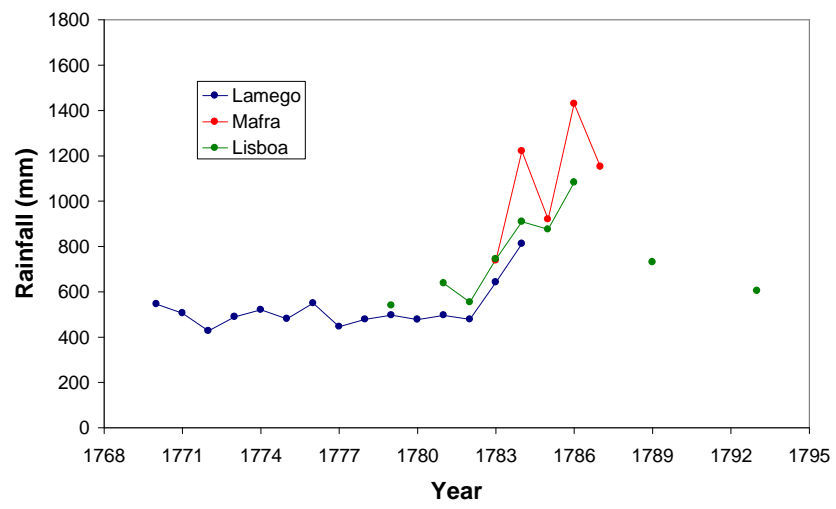

Fig. 4. Annual totals of rainfall in three meteorological Portuguese 2 sites in the 18th century (Taborda et al., 2004).

\subsection{Pretorius and Schulze (Lisbon, 1781-1785, 1789, 1793)}

Two German scientists came to Lisbon as military officers, integrated into the reorganisation of the Portuguese army: Jacob Pretorius and Henry Schulze carried out diversified and highly accurate meteorological observations between 1781 and 1793 (the former) and in 1789 (the latter) (Fig. 2). Their observational activities were primarily directed to climatic variables (Taborda et al., 2004). However their observations also included astronomical events such as aurora (Vaquero and Trigo, 2005a).

The engineer Jacob Chrysostomo Pretorius (Pretorius, hereafter) lived in Portugal from 1762 to 1764 and returned again in 1776. He was then an effective member of the LRAS (Exact Sciences Class), to which he offered several studies, most of them on meteorology. He died in 1798. Franzini (1779-1861), who would carry out meteorological observations in Lisbon from 1815 onwards (1815-1826; 18361861, Nunes, 1997; Alcoforado et al., 1997), wrote that "death did not give him (Pretorius) time to organize his meteorological data and extract the results one could have expected from such information" (quoted by Ferreira, 1944, p. 4). Henry Schulze came to Portugal in 1776, together with Pretorius, and their observations can be considered as being complementary.

Pretorius and Schulze measured temperature, precipitation, pressure, wind, humidity and cloudiness in Lisbon (Fig. 1). There is also information about extreme events, such as thunder, hail, storm and snow. Although there is no direct reference to the instruments they used, Pretorius was aware of the importance of instrument accuracy. He offered the LRAS several studies on meteorological instruments (Pretorius, $1781 \mathrm{a}, \mathrm{b}, \mathrm{c}, 1782 \mathrm{a}, 1786 \mathrm{a}$ and an undated manuscript about a barometer) and we may infer that he chose the instruments very carefully (Taborda et al., 2004).

Referring to Pretorius observations, we only possess data from 1781 to 1785 , and for 1793 , although the series must 
have been longer. It is probable that meteorological observations were carried out continuously by Pretorius from 1777 to 1793 (or more), starting one year after returning to Portugal. Pretorius refers that precipitation in 1784 was higher than that of the preceding years since 1777 (Pretorius, 1785, p. 271). The foundation of the LRAS in 1779 must have given some support to regular observations. Regrettably, we have only one year of readings obtained by Schulze and these are relative to the year of 1789 (Schulze, 1790).

Pretorius carried out his measurements in Lisbon, in the "vicinity of Nossa Senhora das Necessidades Royal Palace" in the south-western part of Lisbon (Fig. 1), most probably in the Fábrica da Pólvora, where he lived (city district of Alcântara, Taborda et al., 2004). Referring to the thermometer, Pretorius states that the instrument was inserted in a box made of "varnished tinplate", "which could be placed near a window facing north or in a wind exposed site, although protected against the sun by means of some wooden boards, located some distance away from the instrument" (Pretorius, $1786 \mathrm{a}$, p. 232, front and back). This means that he was shielding his thermometer, but there is no certainty on its location. Schulze's instruments were also located in Alcântara (Lisbon), $13 \mathrm{~m}$ above sea-level, most probably not far away from Pretorius' observational site.

Pretorius data from 1781 to 1785 were published in four volumes of the Almanach de Lisboa (Pretorius, 1782b, 1783, 1785, 1786b). The Almanach de Lisboa was first edited by the LRAS, but later printed and sold by the French JeanBaptiste Reycend (Taborda et al., 2004). Data for 1781 and 1782 are scarce, although annual precipitation data are supplied. On the contrary for the following years, monthly data and information on extreme events are present. For 1793, a table including annual and monthly meteorological data is appended to a three page manuscript (Pretorius, 1794). Schulze presents a five page manuscript and a table of the same type of that by Pretorius with the synthesis of monthly and annual data for 1789 (Schulze, 1790). Unfortunately, daily data have not been found so far; although both observers indicate the number of days of extreme temperatures, rainfall, and hail (Pretorius, 1794). Precipitation records from Lisbon are included in Fig. 4 and will be analysed in Sect. 4.1. As Schulze and Pretorius's tables (structure, organization, vocabulary) and measurement methodologies are similar, we may suppose that they have worked together or at least that they were aware of each other measurements.

\subsection{Bella (Coimbra, 1781)}

Giovanni Antonio dalla Bella (Bella, hereafter) was a teacher of Physics hired by the Portuguese Government. He came to the Nobles' College of Lisbon in 1766 with the aim of organizing the laboratory of experimental physics of this institution (Carvalho, 1982). After the widespread education reform imposed by the Marquis of Pombal, Bella went to the University of Coimbra in 1773 (Fig. 1). Among his nu- merous experiences, he performed a series of measurements of the magnetic force in relation with the distance in 1781, published later in the Memoirs of the LRAS. In the context of these measurements, he collected temperature and atmospheric pressure records during his experiments. These meteorological records were published in his papers (Bella $1797 \mathrm{a}, \mathrm{b})$. Bella was registering temperature, pressure, direction of wind and state of the atmosphere for each magnetic experiment. In total, there are 52 records during the period 22 March-9 July 1781. Unfortunately, metadata describing his methods and instruments are not available.

\subsection{Velho (Mafra, 1783-1787)}

Joaquim da Assumpção Velho (Velho, hereafter) was vicar of a religious congregation in Coimbra and taught Physics and Mathematics at the Royal College of Mafra (outskirts of Lisbon, Fig. 1). He was also a member of the LRAS.

Velho was the Portuguese 18th century meteorologist who provided the most valuable metadata, such as detailed references about station site, instruments and measurement methods (Taborda et al., 2004). He carried out daily meteorological observations from 1783 to 1787 (Fig. 2) at the Royal College of Mafra that "is situated four to five leagues (22 to $28 \mathrm{~km}$ ) NNW of Lisbon (...) and 500 to 600 feet above sea level" (152 to $182 \mathrm{~m}$ ). He also provides information about the measurement site: "the horizons to the north and the west are entirely free and unobstructed, the southern horizon is somewhat obscured by a chain of hills culminating in the Serra de Cintra, the eastern horizon is the most restricted by a few neighbouring hills" (Velho, 1797a, p. 450). Velho includes three-daily information on air pressure, temperature and precipitation, as well as observations related to the "state of the sky" (nebulosity) and wind direction and speed (that he inferred from cloud and smoke movement). There are still references to several phenomena, such as storms, hail, lightning and thunder.

In 1783, Velho used the barometer built according to Magalhães' expertise. He writes: "The barometer which I use was made in London by the great craftsman Mr. Nairne under the guidance of our fellow-countryman J. J. Magalhães, with all the corrections and additions with which this great master has perfected the instrument. The thermometer, also made in London, by the same craftsman, is made of mercury and was constructed according to Mr. Réaumur principles, but with Mr. Fahrenheit scale. It is constantly exposed to the open air outside a north facing window in my office. The pluviometer consists of a funnel made from sheet of lead with a six inch diameter at the mouth, which catches the rain and ends in a tube from the same material. It passes through a window where it pours the water into a lead cylindrical pot which has the same diameter as the mouth of the funnel. A body floats in this pot and a stick in the centre passes through the cover of the pot. It marks the elevation of the water on a ruler graduated according to the divisions of the French king 
foot" (Velho, 1797a, p. 450). Precipitation data from Mafra is included in Fig. 4 and will be analysed in Sect. 4.1.

Velho indicates very clearly that the thermometer is constantly exposed outside. The position of the instruments outside was advised at the end of the 18th century to make the data more easily comparable and more representative of the area (Kington, 1988). In the following years, Velho changed to another barometer, which he also describes in detail (Velho, 1797b, p. 475). As no other indication concerning instrument type is included, we may infer that no changes occurred in instrument type after 1784.

\subsection{Lopes (Oporto, 1792)}

José Bento Lopes (Lopes, hereafter) was a physician, graduated from the University of Coimbra, and concerned about public health issues. His readings were performed in the city of Oporto (Fig. 1) in 1792 and took place twice a day; in the morning, between 7 and $8 \mathrm{~h}$, and in the afternoon, between 15 and $16 \mathrm{~h}$. Data on air pressure are expressed in English inches while the thermometer had a Fahrenheit scale. Lopes used a hygrometer with 60 subdivisions (30 to measure the degree of dryness and 30 to measure the degree of moisture). The meteorological and medical data were published in volume I of a medical journal (Lopes, 1796).

\subsection{Dorta (Rio de Janeiro, 1781-1788)}

Bento Sanches Dorta (Dorta, hereafter) was an astronomer and geographer sent to Brazil by the Queen D. Maria I of Portugal in charge of a geographical mission, with the main task of determining the actual limits of the Portuguese colony (Carvalho, 1982). He was a member of the LRAS, having published numerous papers in its Memoirs (Dorta, 1797, 1799a, b, 1812a, b).

The sheer quantity and apparent quality of his wide range scientific observations have been used recently in different publications. Thus, Vaquero et al. (2005) showed the added value of the sunspot observation undertaken by Dorta during the solar eclipse that took place on 9 February 1785. Based on the outstanding number of geomagnetic declination measurements observations performed by Dorta, Vaquero and Trigo (2005b) analyzed the instruments and measure methods. Unusual observations of low latitude auroras australis obtained by Dorta between 1781 and 1788 were linked with the geomagnetic declination values carefully registered in his papers and the solar storms that occurred (Vaquero and Trigo, 2006). Furthermore, the observations of Dorta and the out of the ordinary weather conditions, such as abnormal mist (haze) and dry fog that happened in the years following the Lakagígar eruption are dealt with in Trigo et al. (2010). Very recently the meteorological observations of Dorta were used to assess the late 18th century climate of Rio de Janeiro (Farrona et al., 2011).
In the initial collection of instruments (thermometer, pluviometer and evaporation pan), there was not a barometer that only arrived from Europe in 1784. The instruments were located "in the Camera of my room", located 50 spans and 4 inches (i.e. $1.2 \mathrm{~m}$ ) above sea level in Rio de Janeiro (Fig. 1). This camera had three opened windows toward the southwest (Dorta, 1797, p. 346) and was situated in the Castle hill of the city.

Dorta measured other important weather parameters such as rainfall and evaporation and computed the monthly mean value of all these variables. Finally, he registered the eight basic wind directions from which he derived the monthly mean wind direction in the morning and in the afternoon (Dorta, 1812a, p. 76).

Dorta was a keen observer performing seven times per day, from 06:00 to 18:00 LT every two hours during the period 1781-1783, raising to eight times per day after August 1784 until December 1788 (Dorta, 1799a, p. 346). Based on these sub-daily observations, he computed monthly averages, namely mean temperature and pressure in the morning, at midday and in the afternoon. These values were calculated as the arithmetic mean of all the observations made. In the diary he also recorded the maximum and minimum temperature; however, he admitted he did not know if these values were correctly measured because, as mentioned above, he only checked the thermometer at some pre-defined hours throughout the day (Dorta, 1812a, p. 74).

Additionally to these quantitative observations, Dorta was interested in gathering relevant qualitative information describing the state of the sky. As he said, "The four qualities of the day which shape the years, namely: clear, variable, cloudy, overcast; there should add 365" (Dorta, 1812b, p. 115). He computed the monthly mean of number of days of thunder, rain, fog, aurora australis, zodiacal light, and clear, variable and cloudy days. In fact, at the end of each year Dorta summarized all weather patterns observed during that year, where he described the extreme and/or interesting events and he specified the date on which they happened.

\subsection{Murdock (Madeira, 1793-1802)}

William Gourlay, Fellow of the Royal College of Physicians of Edinburgh and physician of the British Factory at Madeira, published in 1811 a treatise on the Natural History of Madeira containing monthly accounts of weather from 1793 to 1802 . For each month, data on monthly temperature and pressure (maximum, minimum and mean) and a description of weather are available (Gourlay, 1811, pp. 39-66).

According to Barral (1854), the observer was James Murdock and the place of observation in Funchal bay (Fig. 1) was named "Sitio do Vale" (Place of the valley) (400 feet, i.e. $122 \mathrm{~m}$, above sea level). Barral (1854) indicates that there are no metadata for this observer and he classified this record doubtful. While temperature time series present a reliable seasonal range and inter-annual variability, the same cannot 


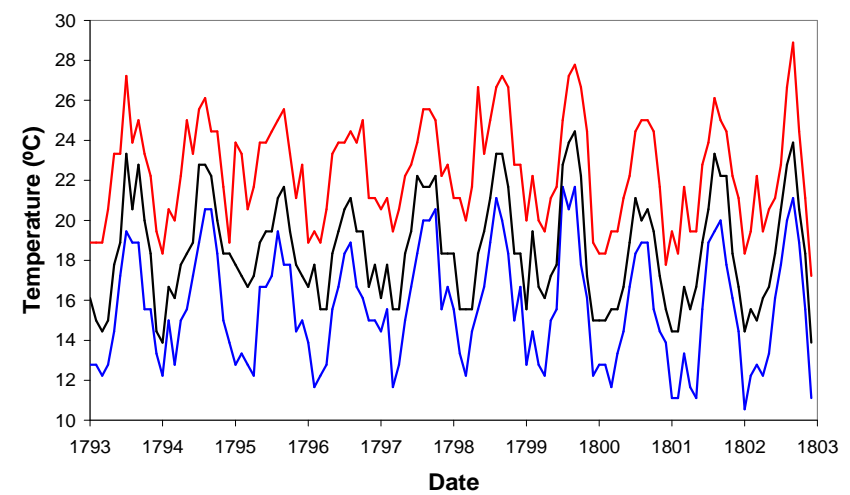

Fig. 5. Maxima (red), minima (blue) and mean (black) temperature at Madeira recorded by Murdock from 1793 to 1802.

be said in relation to the pressure data. In fact, pressure does not present the usual inter-annual variability and the number of consecutive similar values is very high.

Figure 5 shows the temperature record after some minor typographical errors were corrected. The extreme monthly temperatures recorded were $28.9^{\circ} \mathrm{C}$ (September 1802) and $10.6^{\circ} \mathrm{C}$ (January 1802 ). The yearly extreme temperatures recorded were $19.1^{\circ} \mathrm{C}$ and $19.0^{\circ} \mathrm{C}$ (years 1798 and 1799 respectively) and $17.5^{\circ} \mathrm{C}(1800)$. Murdock includes in his observations interesting comments about the state of weather and its relation with agriculture, especially on the plantations at different altitudes.

\section{Illustrating the added value of these observations}

We were able to obtain a considerable amount of data although mostly restricted to a relatively short period between 1780 and 1790. Nevertheless, despite the limited length of data retrieved, it is sufficiently relevant to provide new light over several climatic events that took place during the late 18th century (not only in Continental Portugal but also in the island of Madeira and Rio de Janeiro). Among these events we have selected three case studies that deserve a more in depth analysis as they provide the appropriate stage to illustrate the added value of these observations, namely (a) the assessment of precipitation variability in mainland Portugal in the 1780s, (b) the evaluation of the climatic impact of the Lakakigar eruption in 1783 on continental Portugal and Rio de Janeiro, and (c) the estimation of the level of relationship between the well known NAO index and the precipitation values.

\subsection{Assessment of precipitation variability in mainland Portugal in the 1780s}

Data from Lamego, Lisbon (Lisboa) and Mafra provides sufficient information to characterize the rainfall of the $1780 \mathrm{~s}$ and to confirm Kington's statement (Kington, 1988, p. 2)
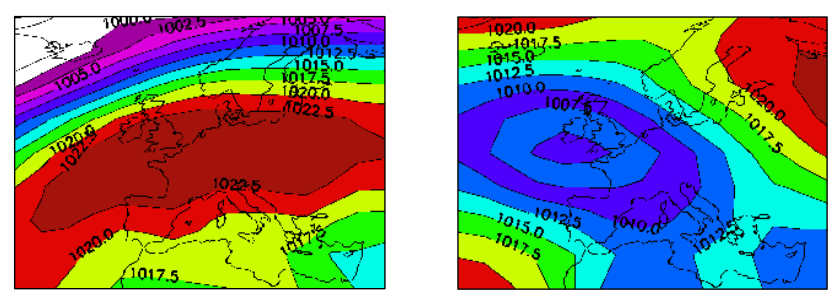

Fig. 6. Reconstruction of monthly sea level pressure fields in Europe in March 1779 (left) and in April 1782 (right) (Luterbacher et al., 2002).

that the 1780s contain several positive and negative rainfall extremes. Similar to other Mediterranean regions (Font Tullot, 1988; Barriendos and Llasat, 2003), an extremely rainy period occurred between 1784 and 1789, preceded and followed by dry periods, as can be observed in Fig. 4, although no conclusions may be drawn relatively to absolute rainfall differences (owing to discrepancies in measurement methodologies and instruments). Data from Lisbon and Lamego, as well as documentary data confirm the occurrence of a drought period in Portugal in 1779, and the corresponding tragic influences on agriculture and water availability (Taborda et al., 2004). This can be related to the persistence of a blocking anticyclone over Central Europe, as confirmed by Luterbacher's sea level pressure (SLP) field reconstructions (Luterbacher et al., 2002a). In this regard, the anticyclone reconstructed for March 1779 would generate an Easterly flow over Iberia (Fig. 6 left).

The three following years were also rather dry $(638.4 \mathrm{~mm}$ in 1781 and $554.9 \mathrm{~mm}$ in 1782 in Lisbon), with the exception of April 1782 when $162.4 \mathrm{~mm}$ were measured by Pretorius. Frequent low pressure centres located SW from the British Isles, as one can infer from SLP reconstructions (Fig. 6 right, Luterbacher et al., 2002a), would have then caused heavy precipitation in Lisbon.

The year 1783 seems to be a turning point, as rainfall increases in Lisbon and Lamego, being followed by further increments in 1784 (Fig. 4). Pretorius (1785, p. 271) writes: "The year of 1784 is the wettest on record in Lisbon since 1777 (...)". In Lisbon, $906.8 \mathrm{~mm}$ of rain were measured in 1784 (162.4 $\mathrm{mm}$ more than in the preceding year) and $1221.4 \mathrm{~mm}$ were recorded in Mafra $(480 \mathrm{~mm}$ more that in 1783). Documentary sources mention that pro-serenitate rogations (Alcoforado et al., 2000) took place in 1784: "If this country has been exempted of intense cold, (...) as is occurring in the rest of Europe, rain has been so continuously strong that the Cardinal Patriarch of Lisbon ordered public rogations in every church, to obtain serenity of the sky" (Newspaper Gazeta de Lisboa, no. 11, 16 March 1784). December 1784 is the wettest month of the Mafra series $(312.5 \mathrm{~mm})$ and was also very rainy in Lisbon $(239.1 \mathrm{~mm})$ (Fig. 7). The highest daily precipitation total was observed at the end of the month (55.1 mm on 29 December, Fig. 8). 


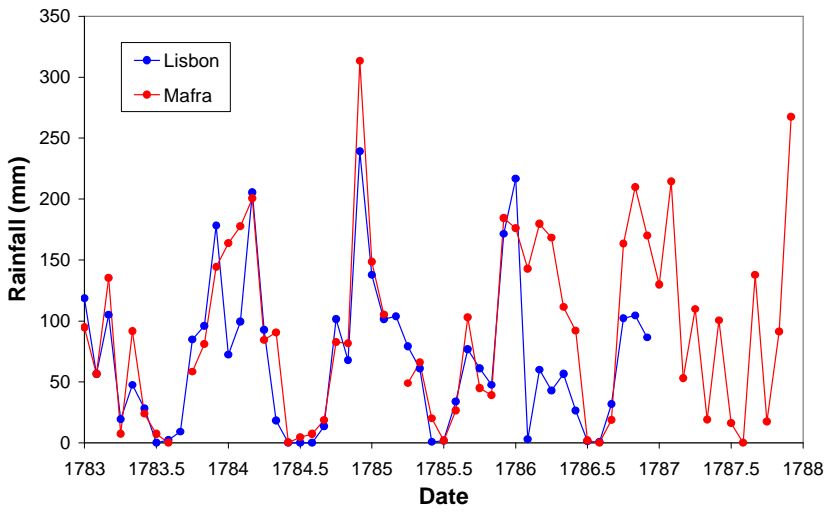

Fig. 7. Monthly rainfall totals in Lisbon and Mafra from 1783 to 1789 .

Taborda et al. (2004) show that the interpretation is in agreement with the daily synoptic charts reconstruction for Europe by Kington (1988), presenting an extensive low pressure centre influencing the Iberian peninsula during the last week of December 1784 (Fig. 9).

Brázdil et al. (2010a) refer the devastating floods that took place in Central Europe in winter and spring 1783-1784. Most of them were due to intense snow melt and heavy rainfall. However, the floods in southern France in December 1783 were mostly caused by sustained rains (Brázdil et al., 2010a). According to our results, December 1783 was also wet in Lisbon and in Mafra, but the precipitation was lower than in December 1784 (Figs. 7 and 8).

The following years of $1785-1787$ can be considered as the continuation of the rainy period (Figs. 4 and 7). Although 1785 is slightly drier than 1784 , total rainfall increased once more in the following years. In Mafra, the 1786 annual value attains $1429.7 \mathrm{~mm}$. From Schulze writings one may infer that precipitation was also in excess of $1000 \mathrm{~mm}$ in Lisbon in 1786 (Schulze, 1790, folio 3 and Taborda et al., 2004). Although one should be careful while comparing with current values, those are certainly very high annual totals: Mafra/Tapada precipitation more recent mean refers to the 1941-1960 period and accounts to $751.6 \mathrm{~mm}$. In Lisboa/Geofísico, the main Lisbon station, the rainfall mean for the 1941-1970 period reaches $714.4 \mathrm{~mm}$; for the 1961-1990 period, it attains $751.7 \mathrm{~mm}$ (standard deviation $=199.8 \mathrm{~mm}$ ). The maximum annual total for the 1961-1990 period in Lisbon was $1361 \mathrm{~mm}$ (in 1963). Moreover, there are further reports of pro serenitate rogations in March 1786 in Lisbon (Newspaper Gazeta de Lisboa, no. 12, 24 March). After 1789, precipitation decreases once more and in 1791 there are documents referring to the lack of water for agriculture in southern Portugal (Taborda et al., 2004).

Although Velho infers wind direction with a crude method (only based on the movement of the clouds and smoke), it is interesting to combine his precipitation and wind data (Fig. 10): the highest rain totals occur predominantly

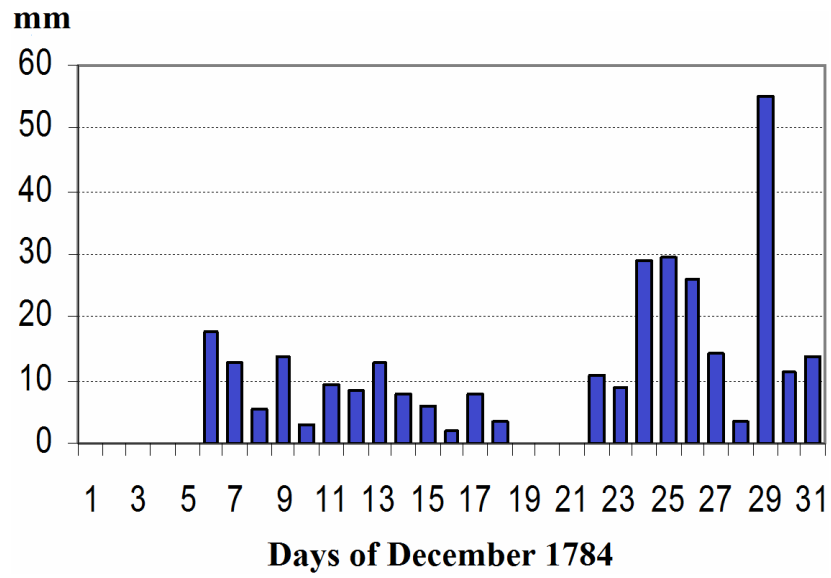

Fig. 8. Daily rainfall amounts in Mafra in December 1784.

with winds from W, SW and S, as Veiga had also noted for Lamego and which is similar to modern climatological analysis (Trigo and Dacamara, 2000; Fragoso and Tildes-Gomes, 2008).

\subsection{Lakagígar eruption impact in $\mathbf{1 7 8 3}$}

The year 1783 deserves particular attention due to "foggy weather" and the "almost permanent fog during day and night", which dominated the state of weather for a considerable number of days during June and July. According to Pretorius (1785, pp. 270 and 272), the extract of meteorological observations on the 1783 and 1784 of this event gives the following testimony: "But what makes this year 1783 more notable among many in the past was the summer haze. Between 22 June and 6 July we had 14 days with a permanent haze throughout the day and night, and shortly thereafter this was succeeded by the same phenomena during 8 days, from 12 to 20 July and it should be noted that the same kind of fog and haze dominated over the boreal hemisphere."

It is now widely accepted among the scientific community that the main culprit for this unusual weather was the Icelandic Lakagígar eruption that took place between June 1783 and February 1784. The amount of gases and aerosols released by Lakagígar (also known simply as Laki) were so large that they provoked widespread impacts in Europe (Thordarson and Self, 2003). These impacts included not only increased mortality in the United Kingdom (Witham and Oppenheimer, 2005) and continental Europe (Grattan et al., 2005), but also the devastation of pastures and livestock in Iceland (Steingrimsson, 1998), and to a less extent in the British Isles, France, and Benelux. The large-scale circulation pattern prevalent at the time advected the plume of smoke and haze towards northern Europe (Stothers, 1999; Demarée et al., 1998), affecting the entire European continent from Lisbon to Moscow (Thordarson and Self, 2003). 

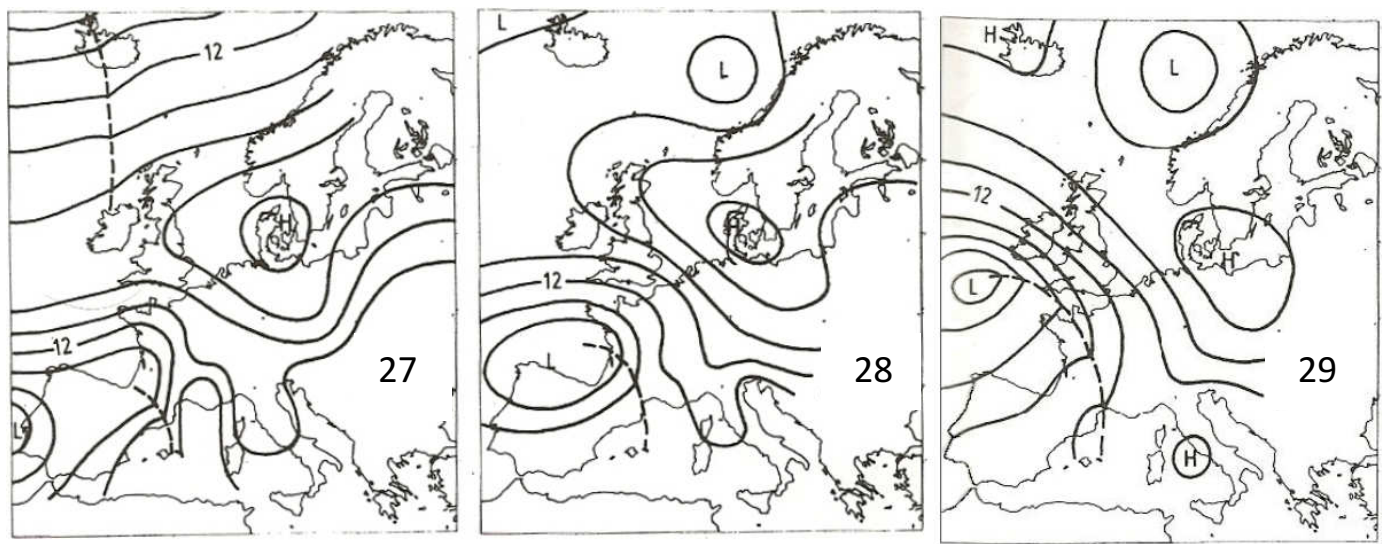

Fig. 9. Reconstruction of daily sea level pressure fields in Europe from 27 to 29 December 1784 (Kington, 1988).

Table 2. Mean annual and summer temperatures $\left({ }^{\circ} \mathrm{C}\right)$ in Mafra (Taborda et al., 2004).

\begin{tabular}{lrrrrr}
\hline Temperature & 1783 & 1784 & 1785 & 1786 & 1787 \\
\hline Mean annual & - & 13.1 & 14.7 & 14.8 & 14.4 \\
$\begin{array}{l}\text { Mean summer } \\
\text { (June, July and August) }\end{array}$ & 17.5 & 17.3 & 19.4 & 19.5 & 18.1 \\
\hline
\end{tabular}

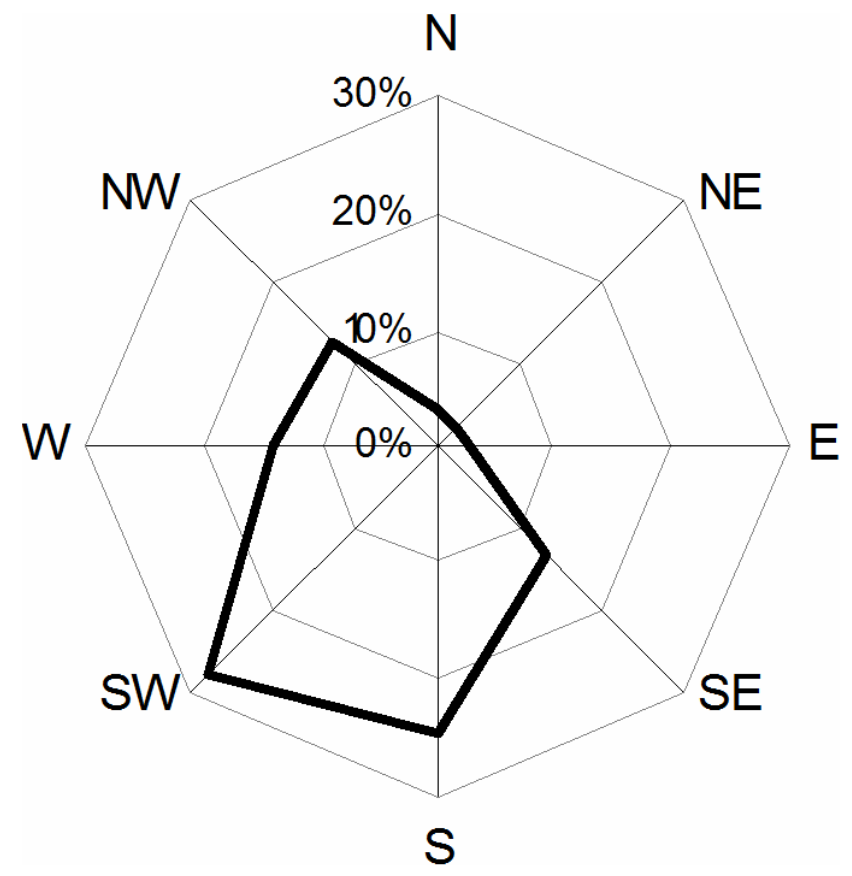

Fig. 10. Percentage of rainfall in Mafra (1783-1787) by wind direction, according with Velho's data (Taborda et al., 2004).

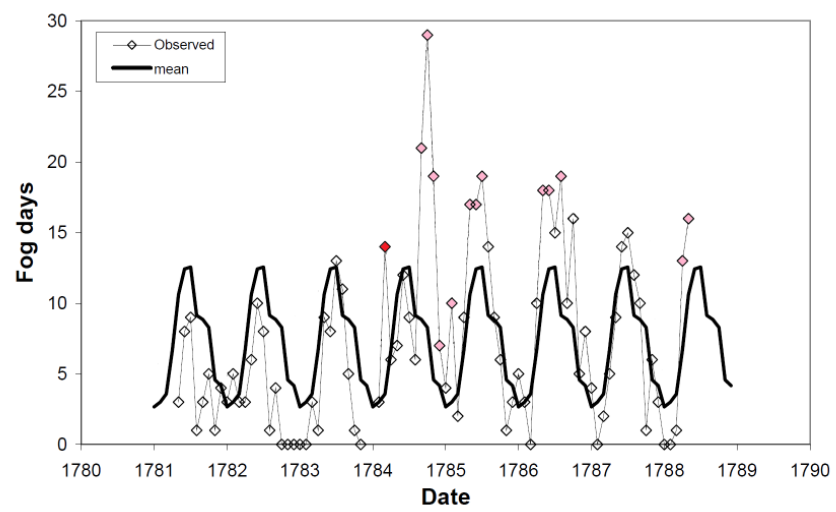

Fig. 11. Monthly values of number of fog days (nfd) recorded by Dorta between 1781 and 1788 compared with the corresponding average (bold line). The outstanding values that lie above the corresponding $1 \sigma(2 \sigma)$ values were filled with pink (red) color.

The year of 1783 is relatively well covered by Portuguese observers, two of them being based in continental Portugal (Pretorius in Lisbon and Velho in Mafra, Taborda et al., 2004), but also with important complementary observations being made in Rio de Janeiro by Dorta (Fig. 11).

In fact, similarly to Pretorius, Velho also recorded foggy and dry fog (haze) during periods that the German refers to, in particular between 26 June and 2 July and between 13 
and 20 July. However, Velho makes further references to fog and misty sky during the months that span between June and August (Taborda et al., 2004). During these three months, $67.2 \%$ of the references to fog and cloudy sky are associated with north and northwest winds and $81.3 \%$ to winds from the north, northwest and west (Taborda et al., 2004).

Perhaps more unexpected is the recent description of possible association between unusual dry fogs over Rio de Janeiro and the Laki eruption, although further work must be done to evaluate the robustness of such a link (Trigo et al., 2010). The progress of the number of foggy days per month witnessed by Dorta between 1781 and 1788 can be seen in Fig. 11.

The summer of 1783 for both sites with observations in Portugal (Lisbon and Mafra) were characterized by relatively mild (even slightly colder) conditions, possibly due to aerosol concentration in the atmosphere that would decrease summer maximum temperatures; on the contrary, most of Western Europe experienced particularly hot weather. As an example, we present and analyse the average summer temperatures in Mafra noticing that in 1783 and 1784 these are circa $2{ }^{\circ} \mathrm{C}$ inferior to those observed in the two following years (Table 2). Thus, in central England, the summer of 1783 and in particular the month of July is considered one of the hottest in the last three centuries (Kington, 1980, 1988); a warmer summer was recorded also in southern Moravia (Brázdil et al., 2003), Germany (Jacobeit, 1997) and Central Europe (Písek and Brázdil, 2006). The most probable physical mechanism responsible for such high temperatures is the existence of persistent blocking patterns that dominated the atmospheric circulation for several months and are known to induce warm and dry conditions in Western Europe (Trigo et al., 2004). In fact, the early summer months of 1783 were dominated by a strong anticyclone over Europe, which promoted the subsiding of air including the dry sulphurous fog towards the surface (see Figs. 6 and 7 in Thordarson and Self, 2003).

\subsection{Correlation between the precipitation and the NAO index between 1780 and 1793}

The North Atlantic Oscillation (NAO) is relatively well known since the early works of Walker (1924) and represents the most important large-scale pattern of circulation in the Northern Hemisphere (Wallace and Gutzler, 1981). In a nutshell, the NAO mode corresponds to a large-scale meridional alternation of atmospheric mass between the polar low pressure system closest to Iceland and the subtropical anticyclone near the Azores (Hurrell, 1995; Trigo et al., 2002). In the last two decades, a growing number of research papers have examined the relationship between winter precipitation in Europe and the NAO index and, especially, for the Iberian Peninsula (Hurrell, 1995; Trigo et al. 2004; Gallego et al., 2005). In particular it has been shown that extreme events such as the outstanding drought of 2005

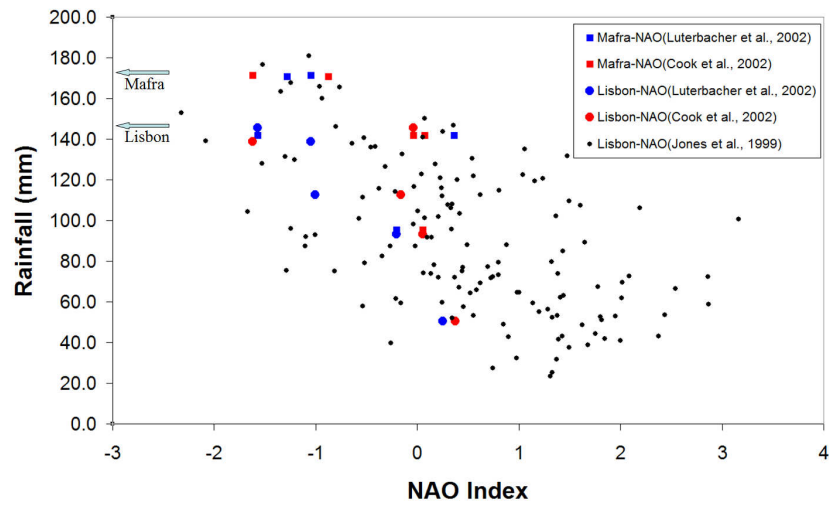

Fig. 12. Relationship between the average monthly precipitation for winter (DJFM) and the winter NAO index (DJFM). Arrows show the values for the 1783-1784 winter (see text for details).

(Garcia-Herrera et al., 2007) and record winter precipitation of 2009-2010 (Vicente-Serrano et al., 2011) are closely related to prolonged episodes of positive and negative values of the NAO index, respectively. Besides the long-term precipitation dataset available for Lisbon since 1865, we now have two additional small datasets of rainfall for the Lisbon region, Lisbon and Mafra (see Sects. 3.3 and 3.5), that we can use to confirm the relationship between winter rainfall in Lisbon during the $1780 \mathrm{~s}$ and the existing reconstructions of the NAO index (Cook et al., 2002; Luterbacher et al., 2002b).

As mentioned in Sect. 4.1, some of the recovered monthly totals of precipitation fall substantially above the average values observed for the more recent long-term period (18652010). For example, the accumulated values of winter precipitation (DJFM) in Lisbon during the winters of 17831784 and 1784-1785 recorded by Pretorius are 555 and $582 \mathrm{~mm}$, respectively. These values correspond to the 89 and 92 percentile values of winter precipitation in the official series of Lisbon during the period 1865-2010. Moreover, the NAO index reconstructions of Luterbacher et al. (2002b) and Cook et al. (2002) show negative or near zero values in the years that have historical records of precipitation in Lisbon and Mafra. Therefore, both data sets are compatible.

The relationship between the average monthly precipitation for winter (DJFM) and the winter NAO index (DJFM) is shown in Fig. 12. The black dots represent the values of the instrumental period (1865-2000). We used the historical rainfall series of Lisbon employed in recent assessment of drought and wet events over western Iberia (Garcia-Herrera et al., 2007; Vicente-Serrano et al., 2011) and the NAO index values provided by Jones et al. (1999). Squares and circles represent the historical values of precipitation of Mafra (1783-1787) and Lisbon (1783-1785, 1789 and 1793), respectively, while colour indicates the origin of the reconstructed NAO index time series: red (Cook et al., 2002) and blue (Luterbacher et al., 2002b). 
In spite of the small set of precipitation data available for Lisbon and Mafra in the late 18th century, it shows a similar behaviour to that provided by the long-term dataset for the modern period (1865-2010). In particular, we can note that the decade of the 1780 s was wetter than the long-term mean in the Lisbon region and that the corresponding reconstructed NAO values were predominately negative.

\section{Discussion and conclusions}

European temperature and precipitation reconstructions clearly point to the fact that more information is still needed for a better understanding of climate change in Europe. Therefore, any new data from Portugal may help bridging existing spatial and temporal gaps in coverage of Southwest Europe. Even though the records are too short to be really useful for the calibration of proxy data, they can nevertheless be useful in large-scale reconstructions similar to the field temperature reconstructions of Luterbacher et al. (2004) and Xoplaki et al. (2005).

The early instrumental data from Portugal and Brazil that were presented in this paper are the first short series available in a period for which climate reconstruction has been mostly based on documentary data (Taborda et al., 2004, Trigo et al., 2009). Systematic observations of different weather elements were encouraged by Scientific Academies and data quality is sometimes very good. Given the novel and innovative nature of the information, some scientists (particularly Velho and Pretorius) were concerned with legitimizing their results through the descriptions concerning instrument exposure, type and location, as well as instrument site. Pretorius and Velho were among the first in Iberia to take their measurements outside (Barriendos at al., 2000). However, most data values may not be directly compared to current ones in absolute terms due to the following facts: (i) instruments were not always properly calibrated; (ii) scales were not normalized; (iii) exact station location and site are often unknown; (iv) instruments (e.g. thermometers) were not shielded (temperatures are often higher than nowadays); and (v) no metadata are available. Although units used by the different observers (or the same observer) are quite different, it has been possible to convert them into SI units.

Similarly to other European countries, early Portuguese meteorologists had to face serious difficulties to carry on regular and reliable observations: (i) the instruments were not easy to get; (ii) as they were often not appropriately shielded, they were frequently damaged by storms; (iii) there were no explicit and general measuring rules; and (iv) most of the observers were not trained (lack of precision in readings, lack of discipline in observation time).

At this stage we believe that the fragmentary nature of these records, coupled with lack of metadata, makes it difficult to be incorporated (as it is) into larger datasets. Despite these facts, the data collected gave information and lead to the understanding of several climatic features of the 18th century in Continental Portugal, Madeira and Rio de Janeiro. As shown in the three examples provided in Sect. 4, these relatively short series provide new light over specific phenomena, such as annual and monthly temperature and precipitation variability (e.g. the very rainy years of the early 1780s in Continental Portugal) and extreme meteorological events. Furthermore, quantitative evidence of the Laki eruption impact in 1783 was supplied for continental Portugal and Rio de Janeiro, and the data also allowed establishing correlations between rainfall and NAO index. Moreover, within our research on precipitation and temperature variability in the 18th century (Taborda et al., 2004; Luterbacher et al., 2006), we have used the short series of Lisbon and Mafra together with documentary data to establish seasonal and yearly precpitation indices. With the instrumental data that we have described here and the documentary data we possess for the period 1780-1790, we are starting the construction of a "calibrating period", that is a period with overlapping instrumental and documentary data (Brázdil et al., 2010b, p. 17), in order to transform Portuguese indices (Alcoforado et al., 2000; Taborda et al., 2004) into precipitation values. Our future objective is to extend this calibrating period well into the beginning of the 19th century and to reconstruct a long series for Southern Portugal.

Acknowledgements. Authors appreciate the comments of three reviewers who improved this manuscript. Support from the Junta de Extremadura, Spanish Science and Innovation Ministry (AYA2008-04864/AYA and AYA2011-25945) and Spanish Environment Ministry, project "Salvà-Sinobas" (reference number 200800050083542) is gratefully acknowledged. Ricardo Trigo (IDL) was supported by Project MEDIATIC (PTDC/AACCLI/103361/2008) funded by the Portuguese Foundation for Science and Technology (FCT). Part of this research has been carried out in the frame of the project Reconstruction and model simulations of past climate in Portugal using documentary and early instrumental sources (17th-19h century) (Klimhist, PTDC/AACCLI/119078/2010) funded by the FCT.

Edited by: F. Domínguez-Castro

\section{References}

Alcoforado, M.-J., Nunes, F., and Garcia, J. C.: Climat et société à Lisbonne avant la mise en place institutionnelle des observations météorologiques, Publications de l'Association Internationale de Climatologie, 10, 75-83, 1997.

Alcoforado, M.-J., Nunes, F., Garcia, J. C., and Taborda, J. P.: Temperature and Precipitation reconstruction in southern Portugal during the Late Maunder Minimum (AD 1675-1715), The Holocene, 10, 333-340, doi:10.1191/095968300674442959, 2000.

Baptista, M. A., Miranda, J. M., Chierici, F., and Zitellini, N.: New study of the 1755 earthquake source based on multi-channel seismic survey data and tsunami modeling, Nat. Hazards Earth Syst. Sci., 3, 333-340, doi:10.5194/nhess-3-333-2003, 2003. 
Barral, F. A.: Notícias sobre o clima do Funchal e sua influência no tratamento da tísica pulmonar, Academia Real das Sciencias, Lisboa, 1854.

Barriendos, M. and Llasat, M. C.: The case of the "Maldá" anomaly in the western Mediterranean basin (ad 1760-1800): an example of a strong climatic variability, Climatic Change, 61, 191-216, 2003.

Barriendos, M., Garcia, J., Martín-Vide, J., Nunes, F., Peñas, J. C., and Alcoforado, M.-J.: 18th century instrumental meteorological series in the Iberian Peninsula, General characteristics and climatic utility in: Giuseppe Toaldo e il suo Tempo (1719-1797), edited by: Pigato, L., Bertoncello Artigraphiche, Padova, 907920, 2000

Barriendos, M., Martín-Vide, J., Peñas, J., and Rodriguez, R.: Daily meteorological observations in Cádiz-S. Fernando. Analysis of the documentary sources and the instrumental data content (1786-1996), Climatic Change, 53, 151-170, 2002.

Bergström, H. and Moberg, A.: Daily air temperature and pressure series for Uppsala (1722-1998), Climatic Change, 53, 213-252, 2002.

Brázdil, R., Demarée, G. R., Deutsch, M., Garnier, E., Kiss, A., Luterbacher, J., Macdonald, N., Rohr, C., Dobrovolný, P., Koláø, P., and Chromá, K.: European floods during the winter 1783/1784: scenarios of an extreme event during the 'Little Ice Age', Theor. Appl. Climatol., 100, 163-189, doi:10.1007/s00704-009-0170-5, 2010a.

Brázdil, R., Dobrovolný, P., Luterbacher, J., Moberg, A., Pfister, C., Wheeler, D., and Zorita, E.: European climate of the past 500 years: new challenges for historical climatology, Climatic Change, 101, 7-40, doi:10.1007/s10584-009-9783-z, 2010b.

Brázdil, R., Pfister, C., Wanner, H., von Storch, H., and Luterbacher, J.: Historical climatology in Europe-The State of the Art, Climatic Change, 70, 363-430, 2005.

Brázdil, R., Valášek, H., and Macková, J.: Climate in the Czech Lands during the 1780s in light of the daily weather records of parson Karel Bernard Hein of Hodonice (southwestern Moravia): Comparison of documentary and instrumental data, Climatic Change, 60, 297-327, 2003.

Camuffo, D.: History of the long series of daily air temperatures in Padova (1725-1998), Climatic Change, 53, 7-75, 2002a.

Camuffo, D.: Calibration and instrumental errors in early measurements of air temperature, Climatic Change, 53, 297-329, 2002b.

Camuffo, D. and Bertolin, C.: The earliest temperature observations in the world: The Medici Network (1654-1670), Climatic Change, 111, 335-363, doi:10.1007/s10584-011-0142-5, 2012.

Camuffo, D. and Jones, P.: Improved understanding of past climatic variability from early daily European instrumental sources, Guest Editorial, Climatic Change, 53, 1-4, 2002.

Camuffo, D., Bertolin, C., Barriendos, M., Dominguez-Castro, F., Cocheo, C., Enzi, S., Sghedoni, M., Valle, A., Garnier, E., Alcoforado, M.-J., Xoplaki, E., Luterbacher, J., Diodato, N., Maugeri, M., Nunes, F., and Rodriguez, R.: 500-year temperature reconstruction in the Mediterranean Basin by means of documentary data and instrumental observations, Climatic Change, 101, 169199, 2010

Carvalho, R.: A Física Experimental em Portugal no século XVIII, Instituto de Cultura e Língua Portuguesa, Série Pensamento e Ciência, 63, Lisboa, 97 p., 1982

Cassidy, D. C.: Meteorology in Mannheim: The Palatine Meteoro- logical Society, 1780-1795, Sudhoffs Archiv, Band 69(1), Franz Steiner Verlag Wiesbaden GmbH, Stuttgart, 8-26, 1985.

Cook, E. R., D’Arrigo, R. D., and Mann, M. E.: A Well-Verified, Multiproxy Reconstruction of the Winter North Atlantic Oscillation Index since AD 1400, J. Climate, 15, 1754-1764, 2002.

Daveau, S.: Répartition et rythme des précipitations au Portugal. Memórias do Centro de Estudos Geográficos, Lisboa, 1977.

Demarée, G. R.: The neo-hippocratic hypothesis - an integrated 18th century view on medicine, climate and environment, in: Zeszyty Naukowe Uniwersytetu Jagiellonskiego, MCLXXXVI, Prace Geograficzne, Zeszyt, 102, 515-518, 1996.

Demarée, G. R.: The Ancien Régime instrumental meteorological observations in Belgium or The physician with lancet and thermometer in the wake of Hippocrates , Vol. 17, Sartoniana, Ghent, 13-41, 2004.

Demarée, G. R., Ogilvie, A. E. J., and Zhang, D.: Further Documentary Evidence of Northern Hemispheric Coverage of the Great Dry Fog of 1783, Climatic Change, 39, 727-730, 1998.

Farrona, A. M. M., Trigo, R. M., Gallego, M. C., and Vaquero, J. M.: The Meteorological Observations of Bento Sanches Dorta, Rio de Janeiro, Brazil: 1781-1788, submitted to Climatic Change, 2011.

Feldman, T.: Late Enlightenment Meteorology, in: The quantifying spirit in the eighteenth century, edited by: Fragsmayr, T., Heilbron, J. L., and Rider, R. E., Berkeley, University of California Press, 143-177, 1990.

Ferreira, H.A.: Observações meteorológicas em Portugal antes da fundação do Observatório do Infante D. Luís, Separata das Memórias da Academia das Ciências de Lisboa, Classe de Ciências, tomo IV, Lisboa, 13 p., 1944.

Font-Tullot, I.: Historia del Clima de España, Cambios Climáticos y sus causas, Instituto Nacional de Meteorología, Madrid, 1988.

Fragoso, M. and Tildes-Gomes, P.: Classification of daily abundant rainfall patterns and associated large-scale atmospheric circulation types in Southern Portugal, Int. J. Climatol., 28, 537-544, 2008.

Gallego, M. C., García, J. A., and Vaquero, J. M.: The NAO signal on daily rainfall series over the Iberian Peninsula, Clim. Res., 29, 103-109, 2005.

García-Herrera, R., Paredes, D., Trigo, R. M., Trigo, I. F., Hernández, E., Barriopedro, D., and Mendes, M. A.: The outstanding 2004/05 drought in the Iberian Peninsula: Associated atmospheric circulation, J. Hydrometeorol., 8, 483-498, 2007.

Golinski, J: British Weather and the Climate of Enlightenment, University of Chicago Press, Chicago, 2007

Gouveia, C. and Trigo, R. M.: The Impacts of the NAO on the Vegetation Activity in Iberia, in: Hydrological, Socioeconomic and Ecological impacts of the North Atlantic Oscillation in the Mediterranean, edited by: Serrano, S. V. and Trigo, R. M., Adv. Glob. Change Res., 46, 113-128, doi:10.1007/978-94-007-13727_9, 2011.

Gouveia, C., Liberato, M. L. R., DaCamara, C. C., and Trigo, R M.: Modelling past and future wine production in the Portuguese Douro Valley", Clim. Res., 48, 349-362, doi:10.3354/cr01006, 2011

Grattan, J., Rabartin, R., Self, S., and Thordarson, T.: Volcanic air pollution and mortality in France 1783-84, C. R. Geosci., 337 641-651, doi:10.1016/j.crte.2005.01.013, 2005.

Humboldt, A. von: Cosmos: A Sketch of the Physical Description 
of the Universe, Vol. 1. Translated by E C Otte, Harper \& Brothers, London, 1858 (translation from the German 1845 edition).

Hann, J. von: Handbook of Climatology, MacMillan, London, 1903 (translation of the German 2nd edition; first edition: 1883).

Hurrell, J. W.: Decadal trends in the north Atlantic oscillation: regional temperatures and precipitation, Science, 269, 676-679, 1995.

Jacobeit, J.: Atlantisch-europäische Bodenluftdruckfelder ombrothermisch anomaler Monate in Mitteleuropa als Hilfsmittel für die synoptische Interpretation analoger Anomalien im historischen Klima und in zukünftigen Klimaszenarien, Petermanns Geographische Mitteilungen, 141, 139-144, 1997.

Jones, P. D., Davies, T. D., Lister, D. H., Slonosky, V., Jónsson, T., Bärring, L., Jönsson, P., Maheras, P., Kolyva-Machera, F., Barriendos, M., Martin-Vide, J., Rodriguez, R., Alcoforado, M.-J., Wanner, H., Pfister, C., Luterbacher, J., Rickli, R., Schuepbach, E., Kaas, E., Schmith, T., Jacobeit, J. and Beck, C.: Monthly mean pressure reconstruction for Europe for the 1780-1995 period, Int. J. Climatol, 19, 347-364, 1999.

Kington, J.: Daily weather mapping from 1781: A detailed synoptic examination of weather and climate during the decade leading up to the French Revolution, Climatic Change, 3, 7-36, 1980.

Kington, J.: The weather of the 1780s over Europe, Cambridge University Press, Cambridge, 164 p., 1988.

Lamb, H. H.: Ancient units used by the pioneers of meteorological measurements, Weather, 41, 230-233, 1986.

Lopes, A., Lopes, S., Matzarakis, A., and Alcoforado, M. J.: The influence of the summer sea breeze on thermal comfort in Funchal (Madeira). A contribution to tourism and urban planning, Meteorol. Z., 20, 553-564, 2011

Lüdecke, C.: Von der Kanoldsammlung (1717-1726) zu den Ephemeriden der Societas Meteorologica Palatina (17811792). Meteorologische Quellen zur Umweltgeschichte des 18. Jahrhunderts. In: Poplow, M. (ed) Landschaften agrarisch-ökonomischen Wissens. Strategien innovativer Ressourcennutzung in Zeitschriften und Sozietäten des 18. Jahrhunderts. Cottbuser Studien zur Geschichte von Technik, Arbeit und Umwelt 30, Waxmann Verlag, Münster u. a., 97-119, 2010

Luterbacher, J., Xoplaki, E., Dietrich, D., Rickli, R., Jacobeit J, Beck C, Gyalistras D, Schmutz C, and Wanner, H.: Reconstruction of sea-level pressure fields over the Eastern North Atlantic and Europe back to 1500, Clim. Dynam. 18, 545-561, doi:10.1007/s00382-001-0196-6, 2002a.

Luterbacher, J., Xoplaki, E., Dietrich, D., Jones, P. D., Davies, T. D., Portis, D.,Gonzalez-Rouco, J. F., von Storch, H., Gyalistras, D., Casty, C., and Wanner, H.: Extending North Atlantic Oscillation reconstructions back to 1500, Atmos. Sci. Lett., 2, 114-124, doi:10.1006/asle.2001.0044, 2002b.

Luterbacher, J., Dietrich, D., Xoplaki, E., Grosjean, M., and Wanner, H.: European seasonal and annual temperature variability, trends, and extremes since 1500, Science, 303, 1499-1503, 2004.

Luterbacher, J., Xoplaki, E., Casty, C., Wanner, H., Pauling, A., Küttel, M., Rutishauser, T., Brönnimann, S., Fischer, E., Fleitmann, D., González-Rouco, F. J., García-Herrera, R., Barriendos, M., Rodrigo, F., Gonzalez-Hidalgo, J. C., Saz, M. A., Gimeno, L., Ribera, P., Brunet, M., Paeth, H., Rimbu, N., Felis, T., Jacobeit, J., Dünkeloh, A., Zorita, E., Guiot, J., Türkes, M., Alcoforado, M.-J., Trigo, R., Nunes, F., Wheeler, D., Tett, S., Mann,
M. E., Touchan, R., Shindell, D. T., Silenzi, S., Montagna, P., Camuffo, D., Mariotti, A., Nanni, T., Brunetti, M., Maugeri, M., Zerefos, C., De Zolt, S., and Lionello, P.: Mediterranean climate variability over the last centuries: A review, in: The Mediterranean Climate: an overview of the main characteristics and issues, edited by: Lionello, P., Malanotte-Rizzoli, P., and Boscolo, R., Elsevier, Amsterdam, The Netherlands, 27-148, 2006.

Luterbacher, J., Koenig, S. J., Franke, J., Van Der Schrier, G., Zorita, E., Moberg, A., Jacobeit, J., Della-Marta,P.,Xoplaki, E., Wheeler, D., Rutishhauser, T., Stossel, M., Wanner, H., Brázdil, R., Dobrovolný, P. Camuffo, D., Bertolin, C., Van Engelen, A., González-Rouco, F., Wilson, R., Pfister, C., Limanowka, D., Nordli, O., Leijonhufvud, L., Soederberg, J., Allan, R., Barriendos, M., Glaser, R., Riemann, D., Hao, Z. and Zerefos, C.: Circulation dynamics and its influence on European and Mediterranean January-April climate over the past half millennium: Results and insights from instrumental data, documentary evidence and coupled climate models, Climatic Change, 2010, 101, 201234, doi:10.1007/s10584-009-9782-0, 2010.

Manley, G.: Central England temperatures: monthly means 1659 to 1973, Q. J. Roy. Meteorol. Soc., 100, 389-405, 1974.

Maugeri, M., Buffoni, L., and Chlistovsky, F.: Daily Milan temperature and pressure series (1763-1998): History of the observations and data and metadata recovery, Climatic Change, 53, 101-117, 2002.

Middleton, W. E. K.: A History of the Thermometer and its use in Meteorology, Johns Hopkins Press, Baltimore, USA, 249 p., 1966.

Middleton, W. E. K.: The History of the Barometer, Baros Books, Wiltshire, UK, 489 p., 1994.

Nunes, M. F.: As observações meteorológicas na Academia das Ciências: uma leitura científica de Lamego (1770-1784), Alcipes e as Luzes, Fundação das Casas de Fronteira e Alorna, Lisboa, $12 \mathrm{p}, 1997$.

Peixoto, P.: A Ciência em Portugal e a Academia das Ciências de Lisboa, Colóquio/Ciências, 19, F. C. G., Lisboa, 71-84, 1997.

Pfister, C. and Bareiss, W.: The climate in Paris between 1675 and 1715 according to the Meteorological Journal of Louis Morin, Frenzel, B., edited by: Pfister C. and Gläser B. Climatic trends and anomalies in Europe 1675-1715, Gustav Fischer, Stuttgart, 151-172, 1994.

Písek, A. and Brázdil, R.: Responses of large volcanic eruptions in the instrumental and documentary climatic data over central Europe, Int. J. Climatol., 26, 439-459, 2006.

Pueyo, G.: La météorologie en France à la fin du XVIII ${ }^{e}$ siècle à travers les publications de la Société Royale d'Agriculture de Paris. La Météorologie, numéro spécial, 6-9, 1995.

Slonosky, V. C.: Wet winters, dry summers? Three centuries of precipitation data from Paris, Geophys. Res. Lett., 29, 1895, doi:10.1029/2001GL014302, 2002.

Slonosky, V. C., Jones, P. D., and Davies, T. D.: Atmospheric circulation and surface temperature in Europe from the 18th century to 1995 , Int. J. Climatol, 21, 63-75, 2001.

Stothers, R.: Volcanic dry fogs, climate cooling, and plague pandemics in Europe and the Middle East, Climatic Change, 42, 713-723, 1999.

Steingrimsson, J.: The Fires of the Earth, Translated into English by Kunz, K. University of Iceland Press, ISBN 9979-54-244-6, 1998. 
Taborda, J. P., Alcoforado, M.-J., and Garcia, J. C.: Climate in southern Portugal in the 18th century. Reconstruction based on instrumental and documentary sources (in Portuguese, with an English summary), Geo-Ecologia, 2, Centro de Estudos Geográficos, Lisboa, 211p, ISBN 972-636-144-3, 2004.

Thordarson, T. and Self, S.: Atmospheric and environmental effects of the 1783-1784 Laki eruption: A review and reassessment, J. Geophys. Res., 108, 4011, doi:10.1029/2001JD002042, 2003.

Trigo, R. M. and DaCamara, C. C.: Circulation weather types and their influence on the precipitation regime in Portugal, Int. J. Climatol., 20, 1559-1581, 2000.

Trigo, R. M., Osborn, T. J., and Corte-Real, J. A.: The North Atlantic Oscillation influence on Europe: climate impacts and associated physical mechanisms, Clim. Res., 20, 9-17, 2002.

Trigo, R. M., Pozo-Vazquez, D., Osborn, T. J, Castro-Diez, Y., Gámis-Fortis, S., and Esteban-Parra, M. J.: North Atlantic Oscillation influence on precipitation, river flow and water resources in the Iberian Peninsula, Int. J. Climatol., 24, 925-944, 2004.

Trigo, R. M., Vaquero, J.-M., Alcoforado, M.-J., Barriendos, M., Taborda, J.P., García-Herrera, R., and Luterbacher, J.: Iberia in 1816, the year without summer, Int. J. Climatol., 29, 99-115, 2009.

Trigo, R. M., Vaquero, J. M., and Stothers, R. B.: Witnessing the impact of 1783-1784 Laki eruption in the Southern Hemisphere, Climatic Change, 99, 535-546, doi:10.1007/s10584-009-9676$1,2010$.

Vaquero, J. M. and Trigo, R. M.: Auroras observed in Portugal in late 18 th century obtained from printed and manuscript meteorological observations, Solar Physics, 231, 157-165, doi:10.1007/s11207-005-1583-7, 2005a.

Vaquero, J. M. and Trigo, R. M.: Results of the Rio de Janeiro magnetic observations 1781-1788, Ann. Geophys., 23, 1881-1887, doi:10.5194/angeo-23-1881-2005, 2005b.

Vaquero, J. M. and Trigo, R. M.: Identification of possible intense historical solar storms during the years 1781-1788 inferred from auroras and geomagnetic observations in Rio de Janeiro, Sol. Phys., 235, 419-432, 2006.

Vaquero, J. M., Trigo, R. M., and Gallego, M. C.: A “lost" sunspot observation in 1785, Astronomische Nachrichten, 326, 112-114, doi:10.1002/asna.200410343, 2005.

Vicente-Serrano, S. M., Trigo, R. M., Liberato, M. L. R., LópezMoreno, J. I., Lorenzo-Lacruz, J., Beguería, S., Morán-Tejeda, H., and El Kenawy, A.: Extreme winter precipitation in the Iberian Peninsula, 2010: anomalies, driving mechanisms and future projections" Clim. Res., 46, 51-65, doi:10.3354/cr00977, 2011

Walker, G. T.: Correlations in seasonal variations of weather, IX, Memories of Indian Meteorological Department, 24, 275-332, 1924.

Wallace, J. M. and Gutzler, D. S.: Teleconnections in the geopotential height field during the Northern Hemisphere winter, Mon. Weather Rev., 109, 784-812, 1981.

Witham, C. S. and Oppenheimer, C.: Mortality in England during the 1783-4 Laki Craters eruption, Bull. Volcanol., 67, 15-26, 2005.

Xoplaki, E., Maheras, P., and Luterbacher, J.: Variability of Climate in Meridional Balkans during the periods 1675-1715 and 17801830 and its impact on human life, Climatic Change, 48, 581615,2001
Xoplaki, E., Luterbacher, J., Paeth, H., Dietrich, D., Steiner, N., Grosjean, M., and Wanner, H.: European spring and autumn temperature variability and change of extremes over the last half millennium, Geophys. Res. Lett., 32, L15713, doi:10.1029/2005GL023424, 2005.

\section{Historical Sources(MS = manuscript sources)}

Bella, G. A.: Memoria I. Sobre a força magnetica, Memorias da Academia Real das Sciencias de Lisboa I, 85-115, 1797a.

Bella, G. A.: Memoria II. Sobre a força magnetica, Memorias da Academia Real das Sciencias de Lisboa I, 116-199, 1797b.

Dorta, B. S.: Observações Meteorologicas. Feitas na Cidade do Rio de Janeiro, Memorias da Academia Real das Sciencias de Lisboa. Tomo I, Lisboa, na Typografia da Academia, 345-378, 1797.

Dorta, B. S.: Observações Astronomicas e Meteorologicas. Feitas na Cidade do Rio de Janeiro no anno de 1784, Memorias de Mathematica e Phisica da Academia Real das Sciencias de Lisboa. Tomo II, Lisboa, na Typografia da Academia, 346-368, 1799a.

Dorta, B. S.: Observações Astronomicas e Meteorologicas. Feitas na Cidade do Rio de Janeiro no anno de 1785, Memorias de Mathematica e Phisica da Academia Real das Sciencias de Lisboa. Tomo II, Lisboa, na Typografia da Academia, 369-401, 1799b.

Dorta, B. S.:Observações Astronomicas e Meteorologicas. Feitas na Cidade do Rio de Janeiro no anno de 1786, Memorias de Mathematica e Phisica da Academia Real das Sciencias de Lisboa. Tomo III, I. Parte, Lisboa, na Typografia da mesma Academia, 68-107, 1812a.

Dorta, B. S.: Observações Astronomicas e Meteorologicas. Feitas na Cidade do Rio de Janeiro no anno de 1787, Memorias de Mathematica e Phisica da Academia Real das Sciencias de Lisboa. Tomo III, I. Parte, Lisboa, na Typografia da mesma Academia, 108-167, 1812b.

Dorta, B. S.: Taboas e Diario Meteorologico, pertencente ao anno de 1788, Memorias de Mathematica e Phisica da Academia Real das Sciencias de Lisboa. Tomo III, I. Parte, Lisboa, na Typografia da mesma Academia, 154-192, 1812c.

Dorta, B. S.: Diario Physico-Meteorologico de Outubro do anno de 1788 da Cidade de S. Paulo na America Meridional e Oriental, Memorias de Mathematica e Phisica da Academia Real das Sciencias de Lisboa. Tomo III, Parte I, Lisboa, na Typografia da mesma Academia, 183-187, 1812d.

Dorta, B. S.: Diario Physico-Meteorologico de Novembro do anno de 1788 da Cidade de S. Paulo na America Meridional e Oriental, Memorias de Mathematica e Phisica da Academia Real das Sciencias de Lisboa. Tomo III, I. Parte, Lisboa, na Typografia da mesma Academia, 188-192, 1812e.

Dorta, B. S.: Diario Physico-Meteorologico de Dezembro do anno de 1788 da Cidade de S. Paulo na America Meridional e Oriental, Memorias de Mathematica e Phisica da Academia Real das Sciencias de Lisboa. Tomo III, I. Parte, Lisboa, na Typografia da mesma Academia, 193-197, 1812f.

Dorta, B. S.: Descripçaõ do Thermómetro, e reduçaõ da sua escala, Collecção das Memórias Fizicas e Económicas offerecidas à Academia Real das Sciencias de Lisboa Que não poderão entrar nas Colleccoens impressas. Série Azul, manuscrito 373, tomo I, (4), fl.25-26A (inclui 2 Tábuas) (MS), undated. 
Gourlay, W.: Observations on the natural history, climate, and diseases of Madeira, during a period of eighteen years (London: J. Callow), 1811.

Heberden, T.: Observations of the Weather in Madeira, Phil. Trans., 47, 357-359, 1751.

Heberden, T.: A continuation of the Account of the Weather in Madeira, Phil. Trans., 48, 617-620, 1753.

Heberden, T.: An Account of the Earthquake felt in the Island of Madeira, Phil. Trans., 52, 155-156, 1761.

Heberden, T.: Observations for settling the Proportion, which the Decrease of Heat bears to the Height of Situation, Phil. Trans., $55,126-128,1765$.

Heberden, T.: Of the Increase and Mortality of the Inhabitants of the Island of Madeira, Phil. Trans., 59, 461-464, 1769.

Heberden, T.: Observations of Immersions and Emersion of Jupiter's first Satellite, made at Funchal, in Madeira, Phil. Trans., 60, 502-503, 1770.

Lopes, J. B.: Anno Medico, que contem as observações meteorologicas, e medicas, feitas na Cidade do Porto em 1792 Porto, 1796.

Pretorius, J. C.: Experiencias sobre o meyo Degráo de Calor em differentes Latitudes feitas por Jac. Chrysostomo Praetorius, Memorias Fizicas e Economicas que não tiveram lugar nas coleçoens da Academia. Série Azul, Ms 374, tomo II, (20), fl.235-238, (MS), 1781a.

Pretorius, J. C.: $1^{o}$ Supplemento a memoria sobre o meyo Degráo de calor, que offerece, para se ajuntar a memoria sobre o mesmo assumpto, por Jac. Chrysost. Praetorius, Memorias Fizicas e Economicas que não tiveram lugar nas coleçoens da Academia. Série Azul, Ms 374, tomo II, (21), fl.239-241, (MS), 1781b.

Pretorius, J. C.: $2^{o}$ Supplemento a memoria sobre o meyo Degráo de calor feito por Jacob Chrysostomo Praetorius, Lisboa 19. de Setembro de 1781. Memorias Fizicas e Economicas que não tiveram lugar nas coleçoens da Academia. Série Azul, Ms 374, tomo II, (22), fl. 243-246, (MS), 1781c.

Pretorius, J. C.: Experiencias feitas com hum termometro n'huma viagem para o Brasil, pelo S.nr Simão Pirez de Sardinha Socio da Academia das Sciencias de Lisboa, juntamente com as Resultas, que dellas se podem tirar. Por Jac. Chrysostomo Praetorius, Lisboa 31. do Julho de 1782. Collecção das Memórias Fizicas e Económicas offerecidas à Academia Real das Sciencias de Lisboa Que não poderão entrar nas Colleccoens impressas. Série Azul, Ms 373, tomo I, (19), fl.244-247, (MS), 1782a.

Pretorius, J. C.: Extracto das Observações Meteorológicas feitas no anno de 1781 em Lisboa na visinhança do Real Palacio de N.S. das Necessidades por Jacob Chrysostomo Pretorius Socio da Academia das Sciencias desta Capital, Almanach de Lisboa para o anno MDCCLXXXII, Lisboa, Officina Patriarcal, 306$310,1782 b$.

Pretorius, J. C.: Extracto das Observações Meteorológicas feitas em Lisboa no anno de 1782 por Jacob Chrysostomo Pretorius Socio da Academia das Sciencias, Almanach de Lisboa para o anno de MDCCLXXXIII. Lisboa, Officina da Academia das Sciencias, 275-260, 1783.

Pretorius, J. C.: Extracto das observações Meteorológicas feitas em Lisboa nos annos de 1783 e 1784 por Jacob Chrysostomo Pretorius Socio da Academia Real das Sciencias, Almanach de Lisboa para o anno de MDCCLXXXV. Lisboa, Officina da Academia Real das Sciencias, 267-276, 1785.
Pretorius, J. C.: Memoria sobre o methodo, para fazer hum termometro, que não só mostra os differentes gráos de calor, mas que descreve tambem a curva de todo o seu curso feito em hum mez e mais tempo, sobre hum papel, com huma precisão, à qual o mais exacto observador não pode chegar; e isso com hum mecanismo muito simples. Ideado, e lido na Assembleia publica da R. Acad. d. Sc. d. Lisboa, pelo Socio della, Jac. Chrysostomo Praetorius 4. do Julho de 1786, Memorias Fizicas e Economicas que não tiveram lugar nas coleçoens da Academia. Série Azul, Ms 374, tomo II, (19), fl.228-234, (MS), 1786a.

Pretorius, J. C.: Extracto das Observações Meteorologicas feitas em Lisboa no anno de 1785 por Jacob Chrysostomo Pretorius Socio da Academia das Sciencias, Almanach de Lisboa para o anno MDCCLXXXVI. Lisboa, Officina da Academia Real das Sciencias, 250-255, 1786b.

Pretorius, J. C.: Annotações e Observações ajuntadas às observações Meteorologicas feitas na Cidade de Rio de Janeiro nos Annos de 1783. 84. 85 pelo $S^{\text {or }}$ Bento Sanches Dorta, Memórias que não tiveram lugar nas collecções. Memórias de Mathemática. Série Azul, manuscrito 352, tomo II, (19), fl.177178, (MS), 1787.

Pretorius, J. C.: Memória sobre as observações meteorológicas do anno de 1793 feitas em Lisboa, offerecida à Real Academia de Sciencias na Sua Assembleia publica, 21 de Maio de 1794, Memórias que não tiveram lugar nas collecções. Memórias de Mathemática. Série Azul, manuscrito 352, tomo I, (17), fl.168171, (MS), 1794.

Pretorius, J. C.: Memoria sobre o Barómetro, Collecção de Memorias Fisicas e Economicas offerecidas à Academia Real das Sciencias de Lisboa, Que não poderão entrar nas Colleccoens impressas. Série Azul, manuscrito 373, tomo I, (20), fl. 248-249, (MS), undated.

Schulze, H.: Observações Meteorológicas no Anno de 1789 por Henrique Schulze, Memórias que não tiveram lugar nas collecções. Memórias de Mathemática. Série Azul, manuscrito 352, tomo I, (18), fl. 173-176 (inclui uma Tabuada), (MS), 1790.

Veiga, J. de S. F. A. B. da.: Observações Meteorológicas feitas em Lamego desde o Anno de 1770 athe o de 1784. Série Azul, manuscrito 990, 17 folhas, (MS), 1784.

Velho, J. A.: Observações Fizicas Por occazião de seis raios que em differentes annos, cahiraõ sobre o Real Edificio junto à Villa de Mafra. Por D. Joaquim da Assumpçaõ Velho, Série Azul, manuscrito 1449, 40 p. (MS), 1786.

Velho, J. A.: Observações Meteorológicas feitas no Real Collegio de Mafra no anno de 1787. Série Azul, manuscrito 992, 14 folhas, (MS), 1787.

Velho, J. A.: Observações Meteorológicas feitas no Real Collegio de Mafra no anno de 1783, Memorias da Academia Real das Sciencias de Lisboa, Tomo I, Lisboa, na Typografia da Academia, 450-474, 1797a.

Velho, J. A.: Observações Metereologicas feitas no Real Collegio de Mafra no anno de 1784, Memorias da Academia Real das Sciencias de Lisboa, Tomo I, Lisboa, na Typografia da Academia, 475-500, 1797b.

Velho, J. A.: Observações Fisicas por occasião de seis raios, que em differentes annos, cahirão sobre o Real Edificio junto à Villa de Mafra, Memorias da Academia Real das Sciencias de Lisboa, Tomo I, Lisboa, na Typografia da Academia, 286-304, 1797c.

Velho, J. A.: Observações Meteorológicas feitas no Real Collegio 
de Mafra no anno de 1785, Memorias de Mathematica e Phisica da Academia Real das Sciencias de Lisboa, Tomo II, Lisboa, na Typografia da Academia, 105-131, 1799a.

Velho, J. A.: Observações Meteorológicas feitas no Real Collegio de Mafra no anno de 1786, Memorias de Mathematica e Phisica da Academia Real das Sciencias de Lisboa, Tomo II, Lisboa, na Typografia da Academia, 132-158, 1799b.
Velho, J. A.: Observações Astronomicas Feitas no Real Collegio de Mafra, Memorias de Mathematica e Phisica da Academia Real das Sciencias de Lisboa, Tomo II, Lisboa, na Typografia da Academia, 512-516, 1799c. 